\title{
Vapor Pressures of Hydrogen, Deuterium, and Hydrogen Deuteride and Dew-Point Pressures of Their Mixtures
}

\author{
Harold J. Hoge ${ }^{2}$ and Robert D. Arnold
}

\begin{abstract}
The vapor pressures of $\mathrm{H}_{2}, \mathrm{HD}$, and $\mathrm{D}_{2}$ have been measured from near their triple points to their critical points. The $\mathrm{H}_{2}$ and $\mathrm{D}_{2}$ samples were catalyzed to ortho-para equilibrium at $20.4^{\circ} \mathrm{K}$. Tables suitable for interpolation have been prepared to represent the results both in centimeter-gram-second and in engineering units.

Measurements of dew-point pressures of several binary mixtures have been made at several pressures below atmospheric. Observed pressures were about 3 percent above those predicted by the law of ideal solutions.
\end{abstract}

\section{Introduction}

Many papers dealing with the vapor pressures of various isotopic varieties of hydrogen have appeared since Dennison [1] ${ }^{3}$ correctly explained the behavior of ortho and para forms in 1927, and since Urey, Brickwedde, and Murphy [2] announced the concentration of deuterium in 1932. So far as we are aware, however, no measurements extending above the range of ordinary mercury manometry had been reported until quite recently, when White, Friedman, and Johnston [3] published data for normal hydrogen extending up to the critical point, and a preliminary report of the present work appeared [4]. Grilly [5] has measured the vapor pressures of the normal varieties of hydrogen, deuterium, and tritium up to approximately $3 \mathrm{~atm}$. Vapor pressures of mixtures had been neglected, there being no information on deviations from the laws of ideal solutions other than that published by Woolley, Scott, and Brickwedde [6, p. 454] for mixtures of ortho and para hydrogen.

The present paper, and one on critical constants [7], being published simultaneously, comprise a full report of a program of determination of the properties of the hydrogens undertaken at the Bureau early in 1950. The work reported in this paper consisted of two parts: the measurement of vapor pressures of $\mathrm{H}_{2}, \mathrm{HD}$, and $\mathrm{D}_{2}$ from low pressures to their critical points; and the measurement of the dew points of a number of binary mixtures of the same substances at pressures below $1 \mathrm{~atm}$. The vaporpressure measurements and the dew-point measurements were performed with different apparatuses, and are discussed separately, the vapor-pressure measurements being presented in section 2 and the dew-point measurements in section 3. Except for a few preliminary measurements, all the vapor pressures reported for $\mathrm{H}_{2}$ and $\mathrm{D}_{2}$ are for samples catalyzed to ortho-para equilibrium at the boiling point of normal hydrogen $\left(20.4^{\circ} \mathrm{K}\right)$. Hydrogen so catalyzed $\left(0.979\right.$ para $-\mathrm{H}_{2}, 0.021$ ortho- $\left.\mathrm{H}_{2}\right)$ has been designated

\footnotetext{
1 This research was supported in part by the Atomic Energy Commission.

${ }^{2}$ Present address, Leeds \& Northrup Co., Philadelphia, Pa.

${ }^{3}$ Figures in brackets indicate the literature references at the end of this paper.
}

e- $\mathrm{H}_{2}$ [6]. Likewise, deuterium catalyzed to equilibrium at $20.4^{\circ} \mathrm{K}\left(0.022\right.$ para- $\mathrm{D}_{2}, 0.978$ ortho- $\left.\mathrm{D}_{2}\right)$ is designated $\mathrm{e}-\mathrm{D}_{2}$. It is worth while to emphasize that $\mathrm{e}-\mathrm{H}_{2}$ and $\mathrm{e}-\mathrm{D}_{2}$ were in ortho-para equilibrium only at $20.4^{\circ} \mathrm{K}$, and that the composition did not change as the temperature was raised or lowered during the course of the measurements. It had been hoped to measure the vapor pressure of normal, or high-temperature-equilibrium hydrogen ( 0.25 para$\mathrm{H}_{2}, 0.75$ ortho- $\left.\mathrm{H}_{2}\right)$ and deuterium (0.3333 para- $\mathrm{D}_{2}$, 0.6667 ortho- $\mathrm{D}_{2}$ ), but time did not permit. There are no separate ortho and para varieties of HD.

\section{Vapor-Pressure Measurements}

\subsection{Apparatus and Methods}

The apparatus and methods were substantially the same as those recently used to measure the vapor pressure of oxygen and are described in reference [8]. The diaphragm cell used for part of the work on oxygen was not employed.

After part of the present work was completed, it was noted that the floating nickel sleeves and magnetic detectors were not indicating correctly the difference in height of the two mercury meniscuses inside the stainless steel U-tube. This was verified by taking $\mathrm{X}$-ray pictures of the meniscuses. The nickel sleeve at the $\mathrm{Hg}-\mathrm{H}_{2} \mathrm{O}$ interface (height $h_{2}$ ) was found to be functioning properly, supported entirely above the mercury by the surface tension of the latter. The sleeve at the $\mathrm{Hg}-\mathrm{H}_{2}$ interface (height $h_{1}$ ), however, had been wetted by the mercury and had sunk into it. Measurements affected by this difficulty were calculated from the value of $h_{2}$ only, by using a curve of $h_{1}+h_{2}$ versus $h_{2}$ plotted from data taken before the trouble developed. There was a considerable range of overlap of the piston-gage measurements with the mercury manometer and the mercury manometer-barometer measurements, in which the various methods were cross-checked from time to time.

The resistance thermometer (L14) that developed a leak during the $\mathrm{O}_{2}$ measurements was removed and replaced by L11 and L28. With the exception of a few check measurements, all the temperatures in the 


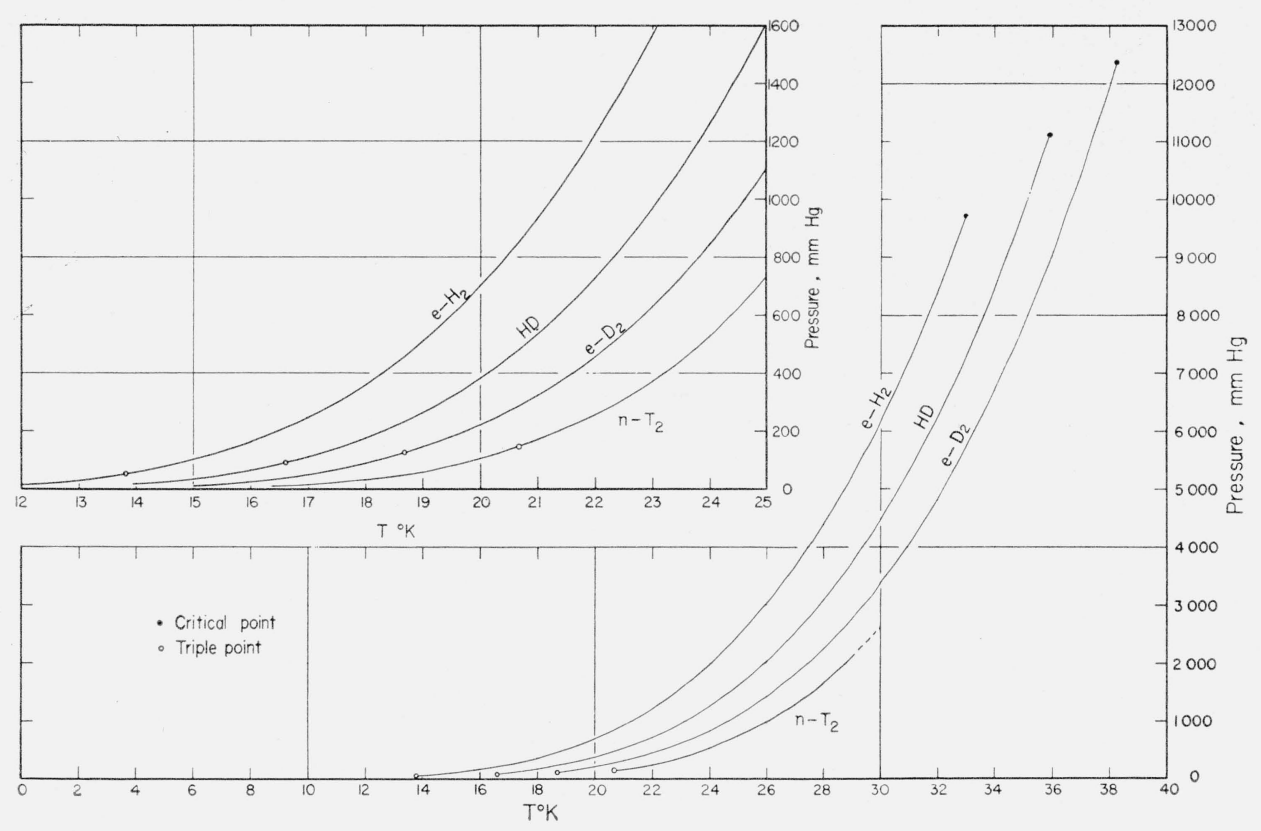

Figure 1. A comparison of the vapor pressures of ordinary hydrogen, hydrogen deuteride, deuterium, and tritium.

present work were measured with platinum resistance thermometer L11. This thermometer is one of the original group used to define the Bureau's temperature scale below $90^{\circ} \mathrm{K}$. Its calibration is discussed in [9].

One improvement was made over the methods used in the oxygen measurements. Rather than make alternate measurements of pressure and of thermometer resistance, it was found more accurate and more convenient to observe the resistance thermometer continuously, keeping the piston gage balanced, until conditions had been steady for several minutes. A valve in the pressure-transmitting line was then closed, after which all the readings associated with the pressure measurement could be made at leisure.

The method of computing pressures was the same as that used for $\mathrm{O}_{2}$ except that no correction was made for the hydrostatic pressure of hydrogen vapor. The maximum correction (at the critical point) in the case of $\mathrm{O}_{2}$ was $6.5 \mathrm{~mm} \mathrm{Hg}$. It was estimated that the corresponding figure for $\mathrm{D}_{2}$ would be about $1 \mathrm{~mm} \mathrm{Hg}$, with the values for $\mathrm{HD}$ and $\mathrm{H}_{2}$ proportionately less.

Preparation and purity of the samples. The $\mathrm{H}_{2}$ was taken from the supply generated by electrolysis of $\mathrm{H}_{2} \mathrm{O}$ for use in this laboratory's hydrogen liquefier. The HD was prepared for us by Abraham Fookson, Philip Pomerantz, and Edwin H. Rich, who used the reaction

$$
\mathrm{LiAlH}_{4}+4 \mathrm{D}_{2} \mathrm{O} \longrightarrow \mathrm{LiOD}+\mathrm{Al}(\mathrm{OD})_{3}+4 \mathrm{HD} .
$$

The $\mathrm{D}_{2}$ was obtained from the Stuart Oxygen Co. Both the HD and the $\mathrm{D}_{2}$ were purified by distillation by Fookson, et al. A more complete report of their work is published elsewhere [10].

A number of samples taken at various stages of the vapor-pressure measurements were submitted to the
Mass Spectrometry Section of the Bureau for analysis. The results are presented in connection with the discussion of the measurements on each particular substance.

\subsection{Ortho-para Catalysis}

The catalyst was $\mathrm{Nd}_{2} \mathrm{O}_{3}$ furnished by the Bureau's Inorganic Chemistry Section. It was a pale blue powder prepared by firing neodymium oxalate at $800^{\circ}$ C. To avoid contaminating the $\mathrm{H}_{2}$ with $\mathrm{D}_{2}$, the catalyst used for $\mathrm{D}_{2}$ was removed and replaced by a fresh sample before measurements on $\mathrm{H}_{2}$ were begun. Each sample was contained in a cylindrical glass chamber of about $1.6-\mathrm{cm}$ inside diameter and $15-\mathrm{cm}^{3}$ volume. Connections were made by two glass tubes, one ending at the top and the other near the bottom of the chamber. About $10 \mathrm{~cm}^{3}$ of catalyst was placed in each chamber and confined with plugs of glass wool. The catalyst was prepared for use by evacuating for several hours near $440^{\circ}$ $\mathrm{C}$, and flushing with small portions of the $\mathrm{H}_{2}\left(\right.$ or $\left.\mathrm{D}_{2}\right)$ to be measured. It was surrounded by liquid hydrogen before use, after which the entire sample of $\mathrm{H}_{2}$ or $\mathrm{D}_{2}$ to be measured was condensed on it. A toepler pump was used to circulate the gas so that all the material would come in contact with the catalyst. When gas was transferred from the catalyzing chamber to the cryostat, it was removed through the tube extending to the bottom of the chamber, so that only material that had been in close contact with the catalyst would be obtained. During the catalytic conversion, samples were condensed in the cryostat from time to time and their vapor pressures were observed; they were then recirculated until no further change in vapor pressure was observed. The time required to reach orthopara equilibrium in the presence of the catalyst at $20.4^{\circ} \mathrm{K}$ appeared to be short compared to the time required to introduce and remove the sample. 


\subsection{The Data}

Figure 1 gives a general picture of the temperature dependence of the vapor pressures of e- $\mathrm{H}_{2}, \mathrm{HD}$, $\mathrm{e}-\mathrm{D}_{2}$, and $\mathrm{n}-\mathrm{T}_{2}$. The curve for tritium is plotted from the data of Grilly [5]; the rest are our own data. On the scale of this graph, curves for different orthopara compositions of the same isotope would scarcely be distinguishable.

The experimental data are given in tables 1,2 , 3 , and 4 . The first three contain the measurements on e- $\mathrm{H}_{2}, \mathrm{HD}$, and $\mathrm{e}-\mathrm{D}_{2}$, respectively. Table 4 contains the results of the first run, which was made on an uncatalyzed sample of $\mathrm{D}_{2}$ taken directly from the supply cylinder. Presumably this sample was normal $\mathrm{D}_{2}$, and since no other measurements were made on $\mathrm{n}-\mathrm{D}_{2}$ these preliminary data are being reported. The supply was analyzed by mass spectrometer, the mole fraction of $\mathrm{D}_{2}$ being $0.99_{2}$; and that of $\mathrm{HD}$, 0.008. The data of table 4 are plotted in figure 3 .

Column 1 of each table contains the run number (preceding the decimal point) and the observation number (following the decimal point) of each datum. Runs are numbered chronologically, as are the observations of a given run. Column 2 of each table shows the type of pressure-measuring equipment used. This was either a mercury manometer $(\mathrm{Hg})$, mercury manometer plus barometer $(\mathrm{HgB})$, or piston gage (PG). Columns 3 and 4 of each table contain the observed temperature and the corresponding observed pressure. From the original data in tables 1,2 , and 3 , three new tables $(5,6$, and 7 ) were derived giving values of $\log _{10} P$ at uniform values of $200 / T$, for $\mathrm{e}-\mathrm{H}_{2} \mathrm{HD}$, and $\mathrm{e}-\mathrm{D}_{2}$, respectively. These tables are suitable for interpolation, and represent the results in essentially the same way that an equation might represent them. Deviations of the experimental data from these tables are given in the final columns of tables 1,2 , and 3 . These deviations are plotted in figure 2. Consecutive points of each run have been joined by straight lines where this could be done without cluttering the graphs too much. A few of the deviations were too large to fall within the range of the graphs. Each of these is indicated by a line extending in the direction of the missing point, and the corresponding deviation can be found in table 1,2 , or 3 . Near the critical point, where isotherms were also measured, all points inside the liquid-vapor dome are included. Where there was more than one point of a run on the horizontal portion of an isotherm, the temperature and pressure given in tables 1,2 , or 3 were obtained by averaging.

After the single run on uncatalyzed (normal) $\mathrm{D}_{2}$, the measurements on $\mathrm{HD}$ were begun. Having no ortho and para forms, this substance requires no catalyst, but the measurements were complicated by slow conversion of $\mathrm{HD}$ into $\mathrm{H}_{2}$ and $\mathrm{D}_{2}$. This is shown best in figure 2 by the rise in pressure in the neighborhood of $31^{\circ} \mathrm{K}$ between successive runs. When liquid hydrogen was not available to keep the cryostat cold, it was our practice not to return the sample to the supply bulb, but to lower the mercury
TABLE 1. Observations of the vapor pressure of $\mathrm{e}-\mathrm{H}_{2}$

The column headed $\Delta P$ contains deviations of the observed values from table 5 .

\begin{tabular}{|c|c|c|c|c|}
\hline $\begin{array}{l}\text { Observa- } \\
\text { tion num- } \\
\text { ber }\end{array}$ & $\begin{array}{l}\text { Pressure- } \\
\text { measuring } \\
\text { system }\end{array}$ & $T$ & $\begin{array}{c}P \\
\text { (observed) }\end{array}$ & $\begin{array}{c}\Delta P \\
\text { (ohserved- } \\
\text { calculated) }\end{array}$ \\
\hline $\begin{array}{l}14.1 \\
14.2 \\
14.3 \\
14.4 \\
14.5 \\
14.6 \\
14.7 \\
14.8 \\
14.9 \\
14.10 \\
14.11\end{array}$ & $\begin{array}{c}\mathrm{Hg} \\
\mathrm{Hg} \\
\mathrm{Hg} \\
\mathrm{Hg} \\
\mathrm{Hg} \\
\mathrm{Hg} \\
\mathrm{Hg} \\
\mathrm{Hg} \\
\mathrm{HgB} \\
\mathrm{HgB} \\
\mathrm{HgB}\end{array}$ & $\begin{array}{c}{ }^{\circ} K \\
17.8294 \\
18.5812 \\
19.1245 \\
20.0401 \\
20.4069 \\
20.5118 \\
16.9549 \\
20.2648 \\
20.5167 \\
20.8655 \\
21.2046\end{array}$ & $\begin{array}{c}m m \mathrm{Hg} \\
338.4 \\
442.1 \\
530.7 \\
707.7 \\
789.6 \\
813.7 \\
241.4 \\
757.1 \\
815.2 \\
900.7 \\
989.8\end{array}$ & $\begin{array}{c}m m \mathrm{Hg} \\
-0.1 \\
-.3 \\
-.1 \\
-.1 \\
.2 \\
-.2 \\
-.2 \\
.1 \\
.1 \\
.0 \\
-.1\end{array}$ \\
\hline $\begin{array}{l}15.1 \\
15.2 \\
15.3 \\
15.4 \\
15.5 \\
15.6 \\
15.7 \\
15.8 \\
15.9 \\
15.10 \\
15.11 \\
15.12 \\
15.13\end{array}$ & $\begin{array}{l}\mathrm{HgB} \\
\mathrm{HgB} \\
\mathrm{PG} \\
\mathrm{PG} \\
\mathrm{PG} \\
\mathrm{PG} \\
\mathrm{PG} \\
\mathrm{PG} \\
\mathrm{PG} \\
\mathrm{PG} \\
\mathrm{PG} \\
\mathrm{PG} \\
\mathrm{PG}\end{array}$ & $\begin{array}{l}20.9513 \\
21.3379 \\
23.6441 \\
24.4501 \\
24.9003 \\
25.5711 \\
26.1980 \\
26.7811 \\
27.4083 \\
28.3858 \\
29.3956 \\
30.3776 \\
31.4021\end{array}$ & $\begin{array}{r}922.1 \\
1026.8 \\
1827.1 \\
2189.4 \\
2414.1 \\
2773.5 \\
3142.6 \\
3517.5 \\
3952.7 \\
4705.7 \\
5583.9 \\
6544.6 \\
7660.2\end{array}$ & $\begin{array}{r}-.6 \\
-.2 \\
-.5 \\
-.1 \\
1.7 \\
0.2 \\
-.7 \\
.4 \\
.0 \\
.8 \\
.2 \\
.5 \\
-4.9\end{array}$ \\
\hline $\begin{array}{l}16.3 \\
16.4 \\
16.5 \\
16.6 \\
16.7 \\
16.8 \\
16.9 \\
16.10 \\
16.11\end{array}$ & $\begin{array}{l}\mathrm{Hg} \\
\mathrm{Hg} \\
\mathrm{PG} \\
\mathrm{PG} \\
\mathrm{PG} \\
\mathrm{PG} \\
\mathrm{PG} \\
\mathrm{PG} \\
\mathrm{PG}\end{array}$ & $\begin{array}{l}16.9752 \\
15.8414 \\
22.2604 \\
22.9058 \\
25.0473 \\
27.8744 \\
29.9173 \\
30.9020 \\
31.8910\end{array}$ & $\begin{array}{r}243.1 \\
149.7 \\
1308.4 \\
1534.9 \\
2488.5 \\
4299.6 \\
6080.2 \\
7102.8 \\
8255.1\end{array}$ & $\begin{array}{r}-0.5 \\
-.3 \\
-.2 \\
-.2 \\
-.0 \\
-.2 \\
-.3 \\
-.8 \\
7.7\end{array}$ \\
\hline $\begin{array}{l}17.1 \\
17.2 \\
17.3 \\
17.4\end{array}$ & $\begin{array}{l}\mathrm{PG} \\
\mathrm{PG} \\
\mathrm{PG} \\
\mathrm{PG}\end{array}$ & $\begin{array}{l}22.2800 \\
22.5792 \\
28.8797 \\
31.0820\end{array}$ & $\begin{array}{l}1313.8 \\
1416.1 \\
5121.5 \\
7302.5\end{array}$ & $\begin{array}{r}-0.9 \\
-1.0 \\
0.2 \\
1.5\end{array}$ \\
\hline $\begin{array}{l}18.1 \\
18.2 \\
18.3 \\
\text { a } 18.6\end{array}$ & $\begin{array}{l}\mathrm{PG} \\
\mathrm{PG} \\
\mathrm{PG} \\
\mathrm{PG}\end{array}$ & $\begin{array}{l}20.9534 \\
21.6873 \\
25.8955 \\
32.8933\end{array}$ & $\begin{array}{r}922.5 \\
1127.2 \\
2960.3 \\
9566.2\end{array}$ & $\begin{array}{r}-0.7 \\
-.4 \\
-.4 \\
3.1\end{array}$ \\
\hline $\begin{array}{r}19.1 \\
\mathrm{~b} 19.4 \\
19.5 \\
19.6 \\
19.7\end{array}$ & $\begin{array}{l}\mathrm{PG} \\
\mathrm{PG} \\
\mathrm{PG} \\
\mathrm{PG} \\
\mathrm{PG}\end{array}$ & $\begin{array}{l}32.8936 \\
32.8926 \\
32.6457 \\
32.3853 \\
32.1392\end{array}$ & $\begin{array}{l}9564.4 \\
9559.3 \\
9219.5 \\
8875.1 \\
8557.7\end{array}$ & $\begin{array}{r}0.6 \\
-2.9 \\
-2.2 \\
0.3 \\
-.5\end{array}$ \\
\hline
\end{tabular}

a Average of four observations.

b Average of three observations.

meniscus, $h_{1}$, so that the sample occupied most of one arm of the stainless steel U-tube. Returning the material to the supply bulb would have made it necessary to remeasure the mass in use for each successive run, and would have lowered the reproducibility of data obtained in the critical region. The pressure of the confined sample rose to about $30 \mathrm{~atm}$ when the cryostat rose to liquid-air temperatures. It is thought that the breakdown of HD to form $\mathrm{H}_{2}$ and $\mathrm{D}_{2}$ occurred principally during periods when most of the sample was inside the stainless steel tube and all of it was at relatively high pressure. In addition to stainless steel, the HD was in contact with nickel, copper, brass, and silver-solder. On completion of the measurements on HD, two samples were taken for mass-spectrometer analysis, one from the 5-liter glass bulb containing the unused portion of the original supply, and another from the sample on which measurements had been made. The analysis of the first sample was $0.99_{8} \mathrm{HD}, 0.001 \mathrm{H}_{2}$, and $0.001 \mathrm{D}_{2}$, in substantial agreement with an earlier analysis made at the time of distillation. 


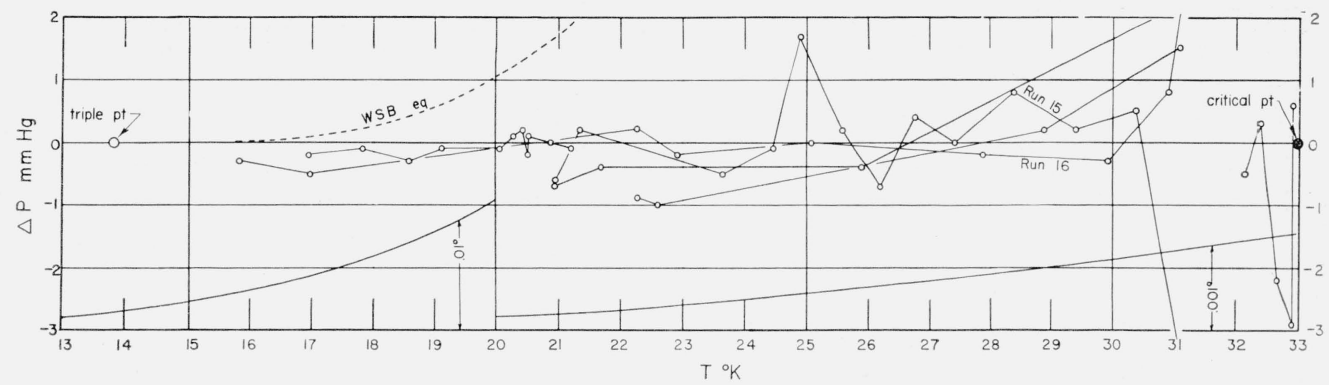

$$
\mathrm{e}-\mathrm{H}_{2}
$$

DEVIATIONS FROM

TABLE 5

(obs - calc)

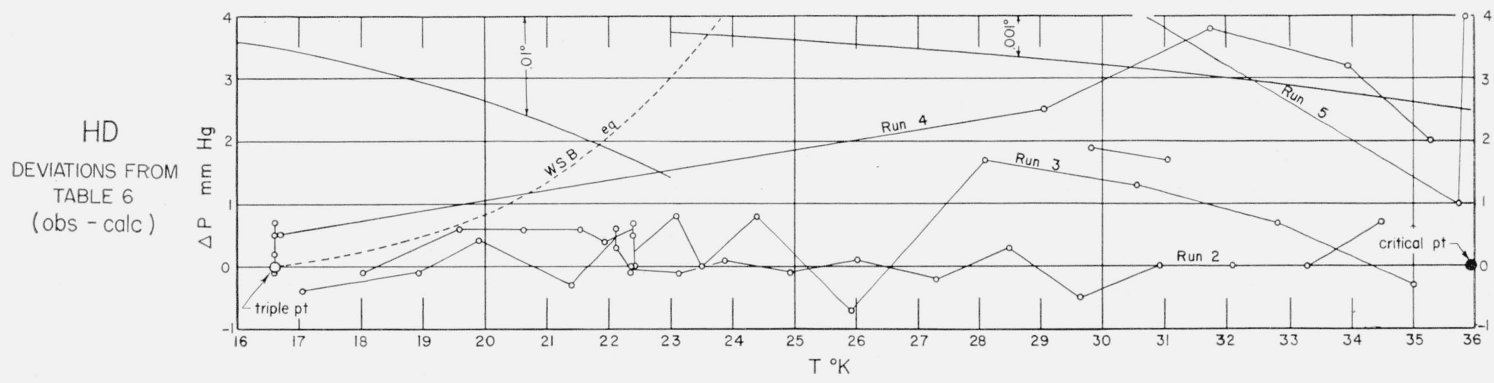

$\mathrm{e}^{-\mathrm{D}_{2}}$

DEVIATIONS FROM

TABLE 7

(obs - calc)

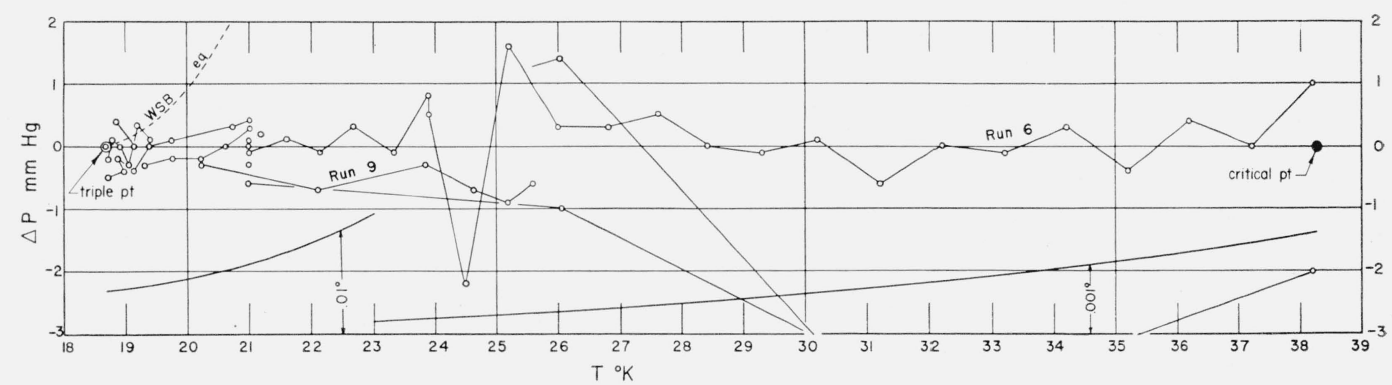

Figure 2. Deviations of the experimental data in tables 1, 2, and 3 from tables 5, 6, and 7 , respectively.

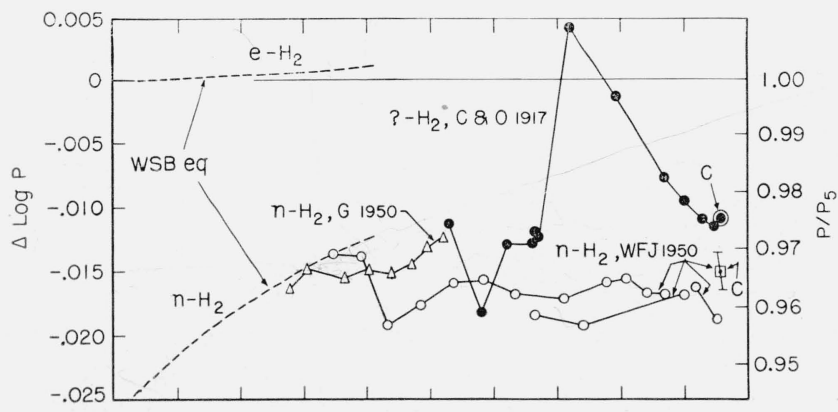

Figure 3. Published vapor-pressure data compared with tables 5 and $\%$.

Above: Published data for $\mathrm{n}-\mathrm{H}_{2}$ compared with table 5. $\Delta \log P=\log P$ (observed) minus $\log P$ (table 5). $P / P_{5}=P$ (observed) $/ P$ (table 5). Below: Pub. lished data for n- $\mathrm{D}_{2}$ compared with table 7. $\Delta \log P=\log P$ (observed) minus $\log P$ (table 7) $\quad P / P_{7}=P$ (observed) $/ P$ (table 7 ). Note that agreement is not to be expected, since in each case the table refers to the equilibrium variety, whereas the plotted points are the normal variety. The lower graph contains one set of data obtained in this research-those of table 4. C \& O, Cath and Onnes; G,

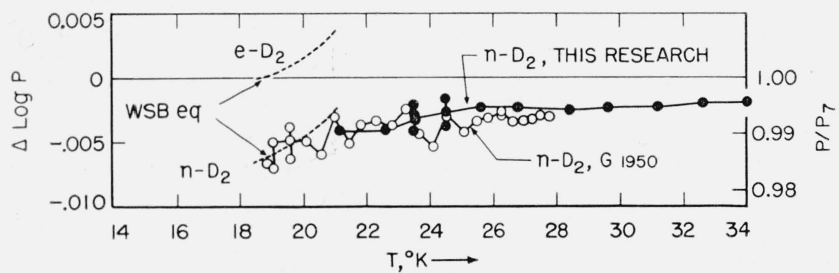

Grilly; W FJ, White, Friedman, and Johnston. C, Critical point. 
TABLE 2. Observations of the vapor pressure of $\mathrm{HD}$

The column headed $\Delta P$ contains deviations of the observed values from table 6 .

\begin{tabular}{|c|c|c|c|c|}
\hline $\begin{array}{l}\text { Observa- } \\
\text { tion num- } \\
\text { ber }\end{array}$ & $\begin{array}{l}\text { Pressure- } \\
\text { measuring } \\
\text { system }\end{array}$ & $T$ & $\begin{array}{c}P \\
\text { (observed) }\end{array}$ & $\begin{array}{c}\Delta P \\
\text { (observed- } \\
\text { calculated) }\end{array}$ \\
\hline $\begin{array}{l}2.1 \\
2.2 \\
2.3 \\
2.4 \\
2.5 \mathrm{a} \\
2.5 \mathrm{~b} \\
2.6 \mathrm{a} \\
2.6 \mathrm{~b} \\
2.7 \\
2.8 \\
2.9 \\
2.10 \\
2.11 \\
2.12 \\
2.13 \\
2.14 \\
2.15 \\
2.16 \\
2.17\end{array}$ & $\begin{array}{l}\mathrm{Hg} \\
\mathrm{Hg} \\
\mathrm{Hg} \\
\mathrm{Hg} \\
\mathrm{Hg} \\
\mathrm{PG} \\
\mathrm{Hg} \\
\mathrm{PG} \\
\mathrm{PG} \\
\mathrm{PG} \\
\mathrm{PG} \\
\mathrm{PG} \\
\mathrm{PG} \\
\mathrm{PG} \\
\mathrm{PG} \\
\mathrm{PG} \\
\mathrm{PG} \\
\mathrm{PG} \\
\mathrm{PG}\end{array}$ & $\begin{array}{c}{ }^{\circ} K \\
17.046 \\
18.935 \\
19.895 \\
21.388 \\
22.121 \\
22.121 \\
22.364 \\
22.364 \\
23.108 \\
23.861 \\
24.920 \\
26.024 \\
27.288 \\
28.492 \\
29.652 \\
30.889 \\
32.098 \\
33.285 \\
34.489\end{array}$ & $\begin{array}{r}m m \mathrm{Hg} \\
114.5 \\
257.6 \\
368.5 \\
604.5 \\
755.3 \\
755.6 \\
810.2 \\
810.3 \\
997.9 \\
1218.2 \\
1584.0 \\
2042.4 \\
2673.9 \\
3393.1 \\
4202.9 \\
5208.5 \\
6344.7 \\
7623.9 \\
9105.5\end{array}$ & $\begin{array}{r}m m \mathrm{Hg} \\
-0.4 \\
-.1 \\
.4 \\
-.3 \\
.3 \\
.6 \\
-.1 \\
.0 \\
-.1 \\
.1 \\
-.1 \\
.1 \\
-.2 \\
.3 \\
-.5 \\
.0 \\
.0 \\
.0 \\
.7\end{array}$ \\
\hline $\begin{array}{l}3.1 \\
3.2 \\
3.3 \\
3.4 \\
3.5 \\
3.6 \\
3.7 \\
3.8 \mathrm{a} \\
3.8 \mathrm{~b} \\
3.8 \mathrm{c} \\
3.9 \\
3.10 \\
3.11 \\
3.12 \\
3.13 \\
3.14 \\
3.15 \\
3.16\end{array}$ & $\begin{array}{l}\mathrm{PG} \\
\mathrm{PG} \\
\mathrm{Hg} \\
\mathrm{Hg} \\
\mathrm{Hg} \\
\mathrm{Hg} \\
\mathrm{Hg} \\
\mathrm{PG} \\
\mathrm{Hg} \\
\mathrm{PG} \\
\mathrm{PG} \\
\mathrm{PG} \\
\mathrm{PG} \\
\mathrm{PG} \\
\mathrm{PG} \\
\mathrm{PG} \\
\mathrm{PG} \\
\mathrm{PG}\end{array}$ & $\begin{array}{l}31.049 \\
29.814 \\
18.007 \\
19.580 \\
20.638 \\
21.554 \\
21.933 \\
22.394 \\
22.394 \\
22.395 \\
23.090 \\
23.506 \\
24.390 \\
25.919 \\
28.096 \\
30.565 \\
32.814 \\
35.0334\end{array}$ & $\begin{array}{r}5351.5 \\
4328.3 \\
176.6 \\
329.2 \\
475.7 \\
637.4 \\
714.6 \\
817.8 \\
818.0 \\
817.6 \\
993.9 \\
1110.4 \\
1393.1 \\
1994.4 \\
3144.8 \\
4931.8 \\
7096.6 \\
9842.1\end{array}$ & $\begin{array}{r}1.7 \\
1.9 \\
-0.1 \\
.6 \\
.6 \\
.6 \\
.4 \\
.5 \\
.7 \\
.0 \\
.8 \\
.0 \\
.8 \\
-.7 \\
1.7 \\
1.3 \\
0.7 \\
-.3\end{array}$ \\
\hline $\begin{array}{l}\text { 4. } 2 \mathrm{a} \\
4.2 \mathrm{~b} \\
4.2 \mathrm{c} \\
4.4 \mathrm{a} \\
4.4 \mathrm{~b} \\
4.5 \\
4.6 \\
4.7 \\
4.8 \\
4.9\end{array}$ & $\begin{array}{l}\mathrm{Hg} \\
\mathrm{Hg} \\
\mathrm{Hg} \\
\mathrm{Hg} \\
\mathrm{Hg} \\
\mathrm{Hg} \\
\mathrm{PG} \\
\mathrm{PG} \\
\mathrm{PG} \\
\mathrm{PG}\end{array}$ & $\begin{array}{l}\text { b } 16.5959 \\
\text { b } 16.5966 \\
\text { b } 16.5982 \\
\text { b } 16.5990 \\
\text { b } 16.5982 \\
16.6718 \\
29.035 \\
31.763 \\
33.948 \\
35.276\end{array}$ & $\begin{array}{r}93.2 \\
93.0 \\
93.0 \\
92.9 \\
92.5 \\
96.5 \\
3759.6 \\
6017.5 \\
8418.3 \\
10188\end{array}$ & $\begin{array}{r}.7 \\
.5 \\
.5 \\
.3 \\
-.1 \\
.5 \\
2.5 \\
3.8 \\
3.2 \\
2\end{array}$ \\
\hline $\begin{array}{r}5.1 \\
\text { c } 5.2 \\
\text { d } 5.3\end{array}$ & $\begin{array}{l}\mathrm{PG} \\
\mathrm{PG} \\
\mathrm{PG}\end{array}$ & $\begin{array}{l}30.374 \\
35.7493 \\
35.8797\end{array}$ & $\begin{array}{l}4775.8 \\
10887 \\
11090\end{array}$ & $\begin{array}{l}4.2 \\
1 \\
4\end{array}$ \\
\hline
\end{tabular}

a A verage of five observations.

b Triple point.

c A verage of six observations.

d A verage of two observations.

The analysis of the material removed from the cryostat, however, was $0.971 \mathrm{HD}, 0.015 \mathrm{H}_{2}$, and $0.014 \mathrm{D}_{2}$. A calculation showed that this amount of decomposition of $\mathrm{HD}$ would raise the vapor pressure about twice as much as was actually observed. This is not surprising, for one would expect a fractionation of the isotopic impurities as the measurements proceeded. Run 2 was made immediately after introduction of HD into the apparatus, and hence presumably before any appreciable decomposition had occurred. Therefore it has been given a much greater weight than any of the other runs in determining the table to represent the vapor pressure of HD.

The measurements on e- $\mathrm{D}_{2}$ were made following removal of $\mathrm{HD}$ from the apparatus. It was found desirable to recatalyze both $\mathrm{e}-\mathrm{D}_{2}$ and $\mathrm{e}-\mathrm{H}_{2}$ to orthopara equilibrium at $20.4^{\circ} \mathrm{K}$ whenever any substantial part of the sample had been at room temperature
TABLE 3. Observations of the vapor pressure of $\mathrm{e}-\mathrm{D}_{2}$ The column headed $\Delta P$ contains deviations of the observed values from table 7 .

\begin{tabular}{|c|c|c|c|c|}
\hline $\begin{array}{l}\text { Observa- } \\
\text { tion num- } \\
\text { ber }\end{array}$ & $\begin{array}{l}\text { Pressure- } \\
\text { measuring } \\
\text { apparatus }\end{array}$ & $T$ & $\begin{array}{c}P \\
\text { (observed) }\end{array}$ & $\begin{array}{c}\Delta P \\
\text { (observed- } \\
\text { calculated) }\end{array}$ \\
\hline $\begin{array}{l}6.1 \mathrm{~d} \\
6.1 \mathrm{e} \\
6.1 \mathrm{f} \\
6.2 \\
6.3 \\
6.4 \\
6.5 \\
6.6 \mathrm{a} \\
6.6 \mathrm{~b} \\
6.7 \\
6.8 \\
6.9 \\
6.10 \\
6.11 \\
6.12 \\
6.13 \\
6.14 \\
6.15 \\
6.16 \\
6.17 \\
6.18 \\
6.19 \\
6.20 \\
\text { a6.21 } \\
6.22 \mathrm{c}\end{array}$ & $\begin{array}{l}\mathrm{Hg} \\
\mathrm{Hg} \\
\mathrm{Hg} \\
\mathrm{Hg} \\
\mathrm{Hg} \\
\mathrm{Hg} \\
\mathrm{Hg} \\
\mathrm{PG} \\
\mathrm{Hg} \\
\mathrm{PG} \\
P G \\
P G \\
P G \\
P G \\
P G \\
P G \\
P G \\
P G \\
P G \\
P G \\
P G \\
P G \\
P G \\
P G \\
P G \\
P G \\
P G \\
P G\end{array}$ & $\begin{array}{c}\circ K \\
20.9914 \\
20.9909 \\
20.9909 \\
21.6127 \\
22.1477 \\
22.6805 \\
23.3317 \\
23.8950 \\
23.8953 \\
24.4938 \\
25.1942 \\
25.9961 \\
26.7961 \\
27.5954 \\
28.3966 \\
29.3002 \\
30.1943 \\
31.1991 \\
32.1980 \\
33.1984 \\
34.1968 \\
35.1947 \\
36.1982 \\
37.1987 \\
38.2017\end{array}$ & $\begin{array}{c}m m \mathrm{Hg} \\
323.1 \\
323.1 \\
322.9 \\
402.0 \\
480.5 \\
570.1 \\
694.7 \\
819.2 \\
818.9 \\
964.4 \\
1165.6 \\
1424.5 \\
1723.6 \\
2064.5 \\
2450.9 \\
2945.8 \\
3501.4 \\
4209.2 \\
5008.4 \\
5910.1 \\
6920.7 \\
8048.2 \\
9311.3 \\
10708 \\
12274\end{array}$ & $\begin{array}{r}m m \mathrm{Hg} \\
0.0 \\
.1 \\
-.1 \\
.1 \\
-.1 \\
.3 \\
-.1 \\
.8 \\
.5 \\
-2.2 \\
1.6 \\
0.3 \\
.3 \\
.5 \\
.0 \\
-.1 \\
.1 \\
-.6 \\
.0 \\
-.1 \\
.3 \\
-.4 \\
.4 \\
0 \\
1\end{array}$ \\
\hline $\begin{array}{l}7.1 \\
7.2 \\
7.3\end{array}$ & $\begin{array}{l}\mathrm{Hg} \\
\mathrm{PG} \\
\mathrm{PG}\end{array}$ & $\begin{array}{l}20.9935 \\
26.0185 \\
32.2375\end{array}$ & $\begin{array}{r}323.1 \\
1432.4 \\
5036.8\end{array}$ & $\begin{array}{r}-0.2 \\
1.4 \\
-5.3\end{array}$ \\
\hline $\begin{array}{r}8.1 \\
8.2 \\
8.3 \\
\text { b8. } 6\end{array}$ & $\begin{array}{l}\mathrm{Hg} \\
\mathrm{PG} \\
\mathrm{PG} \\
\mathrm{PG}\end{array}$ & $\begin{array}{l}20.9875 \\
26.0569 \\
32.2532 \\
38.2034\end{array}$ & $\begin{array}{r}322.0 \\
1444.5 \\
5051.4 \\
12274\end{array}$ & $\begin{array}{l}-0.6 \\
-1.0 \\
-4.1 \\
-2\end{array}$ \\
\hline $\begin{array}{l}9.1 \\
9.15 \\
9.16 \\
9.17 \\
9.18 \\
9.19 \\
9.20\end{array}$ & $\begin{array}{l}\mathrm{Hg} \\
\mathrm{Hg} \\
\mathrm{Hg} \\
\mathrm{Hg} \\
\mathrm{HgB} \\
\mathrm{HgB} \\
\mathrm{HgB}\end{array}$ & $\begin{array}{l}20.9927 \\
20.2347 \\
22.1128 \\
23.8370 \\
24.6055 \\
25.1752 \\
25.5973\end{array}$ & $\begin{array}{r}323.3 \\
243.3 \\
474.4 \\
804.6 \\
995.7 \\
1157.5 \\
1289.5\end{array}$ & $\begin{array}{l}0.1 \\
-.3 \\
-.7 \\
-.3 \\
-.7 \\
-.9 \\
-.6\end{array}$ \\
\hline $\begin{array}{l}10.1 \\
10.2 \\
10.3 \\
10.4 \\
10.5 \\
10.7\end{array}$ & $\begin{array}{l}\mathrm{Hg} \\
\mathrm{Hg} \\
\mathrm{Hg} \\
\mathrm{Hg} \\
\mathrm{Hg} \\
\mathrm{Hg}\end{array}$ & $\begin{array}{l}20.9991 \\
20.6377 \\
20.2178 \\
19.7467 \\
19.3116 \\
21.1878\end{array}$ & $\begin{array}{l}324.3 \\
283.8 \\
241.8 \\
200.7 \\
167.7 \\
346.8\end{array}$ & $\begin{array}{r}.3 \\
.0 \\
-.2 \\
-.2 \\
-.3 \\
.2\end{array}$ \\
\hline $\begin{array}{l}11.1 \mathrm{a} \\
11.1 \mathrm{~b}\end{array}$ & $\begin{array}{l}\mathrm{Hg} \\
\mathrm{Hg}\end{array}$ & $\begin{array}{l}20.9935 \\
20.9944\end{array}$ & $\begin{array}{l}323.0 \\
323.7\end{array}$ & $\begin{array}{r}-.3 \\
.3\end{array}$ \\
\hline $\begin{array}{l}12.1 \\
12.2 \\
12.3 \\
12.4 \\
12.5 \\
12.6 \\
12.7 \\
12.8\end{array}$ & $\begin{array}{l}\mathrm{Hg} \\
\mathrm{Hg} \\
\mathrm{Hg} \\
\mathrm{Hg} \\
\mathrm{Hg} \\
\mathrm{Hg} \\
\mathrm{Hg} \\
\mathrm{Hg}\end{array}$ & $\begin{array}{l}21.0145 \\
20.7220 \\
19.7457 \\
19.3730 \\
19.1332 \\
18.8678 \\
18.9821 \\
18.7098\end{array}$ & $\begin{array}{l}326.2 \\
293.1 \\
200.9 \\
172.4 \\
155.4 \\
138.7 \\
145.6 \\
129.1\end{array}$ & $\begin{array}{r}.4 \\
.3 \\
.1 \\
.0 \\
-.4 \\
-.2 \\
-.4 \\
-.5\end{array}$ \\
\hline $\begin{array}{l}13.1 \\
13.2 \\
13.3 \\
13.4 \\
13.5 \\
13.6 \\
13.20 \\
13.21\end{array}$ & $\begin{array}{l}\mathrm{Hg} \\
\mathrm{Hg} \\
\mathrm{Hg} \\
\mathrm{Hg} \\
\mathrm{Hg} \\
\mathrm{Hg} \\
\mathrm{Hg} \\
\mathrm{Hg}\end{array}$ & $\begin{array}{l}19.3963 \\
19.2038 \\
19.0467 \\
18.9056 \\
18.7684 \\
18.7063 \\
19.1459 \\
18.8379\end{array}$ & $\begin{array}{l}174.2 \\
160.8 \\
149.8 \\
141.2 \\
132.9 \\
129.2 \\
156.9 \\
137.5\end{array}$ & $\begin{array}{r}.1 \\
.3 \\
-.3 \\
.0 \\
.1 \\
-.2 \\
.0 \\
.4\end{array}$ \\
\hline
\end{tabular}

a A verage of three observations.

b Average of two observations.

for periods longer than an hour or two. On some occasions the change of vapor pressure resulting from catalysis of previously uncatalyzed samples was observed, and found to be in substantial agreement with the differences in vapor pressure of normal and equilibrium varieties found by Brickwedde and Scott [6, p. 452]. On removal from the apparatus the mass-spectrometer analysis of the sample was $0.995 \mathrm{D}_{2}$ and $0.005 \mathrm{HD}$. We were somewhat disappointed in this purity, but have no reason to 
TABLE 4. Observations of the vapor pressure of $\mathrm{n}-\mathrm{D}_{2}$

Assumed to be $n-D_{2}$ because no catalyst was used

\begin{tabular}{|c|c|c|c|}
\hline $\begin{array}{c}\text { Observa- } \\
\text { tion num- } \\
\text { ber }\end{array}$ & $\begin{array}{c}\text { Pressure- } \\
\text { measuring } \\
\text { system }\end{array}$ & $T$ & $\begin{array}{c}P \\
\text { (observed) }\end{array}$ \\
\cline { 1 - 1 } & & & \\
\cline { 1 - 1 } 1.1 & $\mathrm{Hg}$ & 21.124 & $m m \mathrm{Hg}$ \\
1.2 & $\mathrm{Hg}$ & 22.612 & 335.6 \\
$1.3 \mathrm{a}$ & $\mathrm{Hg}$ & 23.563 & 738.5 \\
$1.3 \mathrm{~b}$ & $\mathrm{PG}$ & 23.560 & 737.3 \\
$1.3 \mathrm{c}$ & $\mathrm{PG}$ & 23.510 & 729.0 \\
$1.3 \mathrm{~d}$ & $\mathrm{Hg}$ & 23.511 & 725.5 \\
& & & \\
$1.4 \mathrm{a}$ & $\mathrm{HgB}$ & 24.545 & 974.1 \\
$1.4 \mathrm{~b}$ & $\mathrm{PG}$ & 24.546 & 976.9 \\
$1.4 \mathrm{c}$ & $\mathrm{HgB}$ & 24.560 & 975.6 \\
1.5 & $\mathrm{PG}$ & 25.596 & 1283.0 \\
1.6 & $\mathrm{PG}$ & 26.787 & 1710.6 \\
& & & \\
1.7 & $\mathrm{PG}$ & 28.454 & 2466.1 \\
1.8 & $\mathrm{PG}$ & 29.639 & 3131.4 \\
1.9 & $\mathrm{PG}$ & 31.216 & 4201.0 \\
1.10 & $\mathrm{PG}$ & 32.604 & 5337.2 \\
1.11 & $\mathrm{PG}$ & 34.110 & 6800.6 \\
& & & \\
\hline & & & \\
& & &
\end{tabular}

doubt the accuracy of this analysis. Some memory effect was present in the mass spectrometer, but this was eliminated by use of a reference sample, which, by repeated runnings, was found to have a purity of $0.998 \mathrm{D}_{2}$. Analysis of our sample was then made by comparing it with the reference sample. We feel that the sample was at least as pure as the analysis indicated. No correction has been made for impurity.

A large number of measurements were made on e- $\mathrm{D}_{2}$ near the triple point, both on the solid and on the liquid. Unfortunately, the apparatus was found to be poorly suited to rapid work in this region. Unless the apparatus was cooled very slowly, a section of the pressure-transmitting tube would become colder than the equilibrium chamber and the tube would become plugged with solid. As a result, the fraction of the observations below the triple point that were obviously bad was so large that all have been rejected. Just above the triple point the situation was better, but a considerable number of observations have been rejected. The deviations of the rejected points were almost all very large compared to those of the points plotted in figure 2. They were almost always negative, indicating that the plug of solid in the tube remained for some time below the temperature of the equilibrium chamber.

Before introducing $\mathrm{H}_{2}$, the final substance, into the apparatus, the catalyzing chamber used for $\mathrm{e}-\mathrm{D}_{2}$ was removed and a similar one containing fresh catalyst substituted. No attempt was made to carry the measurements on e- $\mathrm{H}_{2}$ very near to the triple point. When removed from the apparatus, the sample on which measurements had been made. was analysed by mass spectrometer. The analysis was $0.999 \mathrm{H}_{2}$ and $0.001 \mathrm{HD}$. The only known source of deuterium contamination was desorption of the previous sample from the interior of the apparatus, which would hardly be expected to yield 1 per mill of HD. However, 1 per mill is the estimated uncertainty of the mass-spectrometer analyses, so this amount of HD is hardly a cause for concern.

\subsection{Deriving the Smoothed Tables}

Tables 5, 6, and 7, used in lieu of equations to represent the vapor-pressure-versus-temperature relation for each substance, were derived from the original data by the use of deviation plots. Various forms of equation were used. For e- $\mathrm{H}_{2}$, for example, the equation of Woolley, Scott, and Brickwedde [6, p. 454] was used below about $28^{\circ} \mathrm{K}$, in which range the observed values of $\log _{10} \mathrm{P}$ do not deviate from the equation by more than about 0.00300 . Between $28^{\circ}$ and the critical point a different form of equation was used that had a smaller curvature near the critical point. Deviations of the observations from the equations were plotted versus the temperature, with a considerable range of overlap of the two equations. Smooth curves were drawn through the points. On these the temperatures corresponding to the values of $200 / T$ appearing in table 5 were marked. At each of these temperatures the ordinate $\left(\log _{10} P_{\text {obs }}-\log _{10} P_{\text {calc }}\right)$ was read and recorded. The equation was evaluated at the same temperatures and the ordinates of the smooth deviation curve added to the corresponding values of the equation.

The resulting table was differenced to third differences on an Underwood-Sundstrand automatic accounting machine. The table was smoothed by inspection of the differences, and redifferenced. The final result was table 5. Similar procedures, with minor variations, led to tables 6 and 7 . For HD, the equation

$$
\log _{10} P=A+(B / T)+C\left(\frac{100}{T}-D\right)^{\alpha}
$$

was used throughout the entire liquid range. Above $24^{\circ} \mathrm{K}$ it represents the data almost within the experimental error, and the deviations at lower temperatures are small enough for satisfactory plotting. The value of $D$ used was 2.5 , or approximately $90 / T_{c}$, and the exponent, $\alpha$, was 0.71 .

Tables 5, 6, and 7 are given in pressure units of millimeters of mercury, atmospheres, and pounds per square inch absolute; and in temperature units of degrees Kelvin and Rankine having been prepared in this form for inclusion in the NBS-NACA series of Tables of Thermal Properties of Gases [11]. For purposes where accurate interpolation is not necessary, it is more convenient to have tables with $T$ as argument rather than $200 / T$. Hence table 8 , giving vapor pressures of all three varieties at temperature intervals of $1 \mathrm{deg} K$ has been calculated from tables 5,6 , and 7 . Table 9 contains the triple points and boiling points. Critical points are given in reference [7].

\subsection{Comparison With Previous Work}

The survey paper of Woolley, Scott, and Brickwedde [6], which appeared in 1948, contains an adequate summary of vapor-pressure data for the hydrogens published up so that time. Their paper 
TABLE 5. Vapor pressure of liquid $\mathrm{e}-\mathrm{H}_{2}$ (for interpolation)

Interpolation with $200 / T$ as argument is more accurate and also more convenient than interpolation with $T$ as argument. Linear interpolation introduces no significant errors below about $23^{\circ} \mathrm{K}$. Between $23^{\circ}$ and $30^{\circ} \mathrm{K}$ linear interpolation is slightly inferior to higher-order interpolation, and above $30^{\circ} \mathrm{K}$ higher-order interpolation should be used if accurate values are required

\begin{tabular}{|c|c|c|c|c|c|c|c|}
\hline$\frac{200}{T}$ & $T$ & \multicolumn{3}{|c|}{$\log _{10} P$} & $\Delta$ & \multirow{2}{*}{$\begin{array}{c}T \\
R\end{array}$} & \multirow{2}{*}{$\frac{\frac{360}{T}}{{ }^{\circ} R^{-1}}$} \\
\hline${ }^{\circ} K^{-1}$ & ${ }^{\circ} K$ & $\mathrm{~mm} \mathrm{Hg}$ & atm & psia & & & \\
\hline 14.5 & 13. 793 & (1. 7176$)$ & $\mathrm{a}(8.8368)$ & $(0.0040)$ & 242 & 24.828 & 14.5 \\
\hline 14.4 & 13.889 & 1. 7418 & 8.8610 & .0282 & 242 & 25.000 & 14.4 \\
\hline 14.3 & 13.986 & 1. 7660 & 8.8852 & .0524 & 242 & 25.175 & 14.3 \\
\hline 14. 2 & 14.085 & 1. 7902 & 8. 9094 & .0766 & 242 & 25. 352 & 14.2 \\
\hline 14.1 & 14. 184 & 1. 8144 & 8. 9336 & .1008 & 243 & 25.532 & 14.1 \\
\hline 14.0 & 14.286 & 1. 8387 & 8. 9579 & .1251 & 243 & 25. 714 & 14.0 \\
\hline 13.9 & 14. 388 & 1. 8630 & 8. 9822 & .1494 & 244 & 25.899 & 13.9 \\
\hline 13.8 & 14.493 & 1.8874 & 9.0066 & .1738 & 244 & 26.087 & 13.8 \\
\hline 13.7 & 14.599 & 1. 9118 & 9.0310 & .1982 & 244 & 26.277 & 13.7 \\
\hline 13.6 & 14. 706 & 1. 9362 & 9. 0554 & .2226 & 244 & 26.471 & 13.6 \\
\hline 13.5 & 14.815 & 1. 9606 & 9. 0798 & .2470 & 245 & 26.667 & 13.5 \\
\hline 13.4 & 14.925 & 1. 9851 & 9. 1043 & .2715 & 245 & 26.866 & 13.4 \\
\hline 13.3 & 15.038 & 2. 0096 & 9.1288 & .2960 & 245 & 27. 068 & 13.3 \\
\hline 13.2 & 15.152 & 2. 0341 & 9.1533 & .3205 & 246 & 27.273 & 13.2 \\
\hline 13.1 & 15.267 & 2. 0587 & 9. 1779 & .3451 & 247 & 27.481 & 13.1 \\
\hline 13.0 & 15.385 & 2. 0834 & 9. 2026 & .3698 & 246 & 27. 692 & 13.0 \\
\hline 12.9 & 15.504 & 2. 1080 & 9. 2272 & .3944 & 247 & 27.907 & 12.9 \\
\hline 12.8 & 15.625 & 2. 1327 & 9. 2519 & .4191 & 247 & 28.125 & 12.8 \\
\hline 12.7 & 15. 748 & 2. 1574 & 9.2766 & .4438 & 248 & 28. 346 & 12.7 \\
\hline 12.6 & 15.873 & 2. 1822 & 9. 3014 & .4686 & 248 & 28.571 & 12.6 \\
\hline 12.5 & 16.000 & 2. 2070 & 9. 3262 & .4934 & 249 & 28.800 & 12.5 \\
\hline 12.4 & 16.129 & 2. 2319 & 9.3511 & .5183 & 249 & 29. 032 & 12.4 \\
\hline 12.3 & 16. 260 & 2. 2568 & 9.3760 & .5432 & 250 & 29. 268 & 12.3 \\
\hline 12.2 & 16.393 & 2. 2818 & 9. 4010 & .5682 & 250 & 29.507 & 12.2 \\
\hline 12.1 & 16.529 & 2. 3068 & 9.4260 & .5932 & 250 & 29.752 & 12.1 \\
\hline 12.0 & 16.667 & 2. 3318 & 9. 4510 & .6182 & 251 & 30.000 & 12.0 \\
\hline 11.9 & 16.807 & 2. 3569 & 9.4761 & .6433 & 251 & 30.253 & 11.9 \\
\hline 11.8 & 16.949 & 2. 3820 & 9.5012 & .6684 & 252 & 30.508 & 11.8 \\
\hline 11.7 & 17.094 & 2. 4072 & 9.5264 & .6936 & 252 & 30. 769 & 11.7 \\
\hline 11.6 & 17.241 & 2. 4324 & 9.5516 & .7188 & 253 & 31.034 & 11. 6 \\
\hline 11.5 & 17.391 & 2. 4577 & 9. 5769 & .7441 & 254 & 31.304 & 11.5 \\
\hline 11.4 & 17.544 & 2. 4831 & 9. 6023 & .7695 & 254 & 31.579 & 11.4 \\
\hline 11.3 & 17. 699 & 2. 5085 & 9.6277 & .7949 & 255 & 31.858 & 11.3 \\
\hline 11.2 & 17.857 & 2. 5340 & 9. 6532 & .8204 & 255 & 32.143 & 11.2 \\
\hline 11.1 & 18.018 & 2. 5595 & 9.6787 & .8459 & 256 & 32.432 & 11.1 \\
\hline 11.0 & 18.182 & 2. 5851 & 9. 7043 & .8715 & & 32.728 & 11.0 \\
\hline 11.0 & 18. 182 & 2. 58506 & 9. 70425 & .87144 & 2564 & 32.728 & 11.0 \\
\hline 10.9 & 18.349 & 2. 61070 & 9. 72989 & .89708 & 2571 & 33.028 & 10.9 \\
\hline 10.8 & 18.519 & 2. 63641 & 9.75560 & .92279 & 2578 & 33.334 & 10.8 \\
\hline 10.7 & 18.692 & 2. 66219 & 9.78138 & .94857 & 2585 & 33. 646 & 10.7 \\
\hline 10.6 & 18.868 & 2. 68804 & 9.80723 & .97442 & 2591 & 33.962 & 10.6 \\
\hline 10.5 & 19.048 & 2. 71395 & 9. 83314 & 1. 00033 & 2598 & 34. 286 & 10.5 \\
\hline 10.4 & 19. 231 & 2. 73993 & 9.85912 & 1. 02631 & 2606 & 34.616 & 10.4 \\
\hline 10.3 & 19.417 & 2. 76599 & 9.88518 & 1. 05237 & 2613 & 34.951 & 10.3 \\
\hline 10.2 & 19.608 & 2. 79212 & 9. 91131 & 1. 07850 & 2621 & 35. 294 & 10. 2 \\
\hline 10.1 & 19.802 & 2. 81833 & 9.93752 & 1. 10471 & 2628 & 35.644 & 10.1 \\
\hline 10.0 & 20.000 & 2. 84461 & 9.96380 & 1. 13099 & 2637 & 36.000 & 10.0 \\
\hline 9.9 & 20.202 & 2. 87098 & 9. 99017 & 1. 15736 & 2646 & 36.364 & 9.9 \\
\hline 9.8 & 20.408 & 2. 89744 & 0.01663 & 1. 18382 & 2654 & 36.734 & 9.8 \\
\hline 9.7 & 20.619 & 2. 92398 & .04317 & 1. 21036 & 2663 & 37.114 & 9.7 \\
\hline 9.6 & 20.833 & 2. 95061 & .06980 & 1. 23699 & 2672 & 37.499 & 9.6 \\
\hline 9.5 & 21.053 & 2. 97733 & .09652 & 1. 26371 & 2682 & 37.895 & 9.5 \\
\hline 9.4 & 21. 277 & 3. 00415 & .12334 & 1. 29053 & 2692 & 38. 299 & 9.4 \\
\hline 9.3 & 21.505 & 3. 03107 & .15026 & 1. 31745 & 2702 & 38. 709 & 9.3 \\
\hline 9.2 & 21. 739 & 3. 05809 & .17728 & 1. 34447 & 2712 & 39.130 & 9.2 \\
\hline 9.1 & 21.978 & 3. 08521 & .20440 & 1. 37159 & 2723 & 39.560 & 9.1 \\
\hline 9.0 & 22.222 & 3. 11244 & .23163 & 1. 39882 & 2735 & 40.000 & 9.0 \\
\hline 8.9 & 22.472 & 3. 13979 & .25898 & 1. 42617 & 2746 & 40.450 & 8.9 \\
\hline 8.8 & 22.727 & 3. 16725 & .28644 & 1. 45363 & 2758 & 40. 909 & 8.8 \\
\hline 8.7 & 22.989 & 3. 19483 & .31402 & 1. 48121 & 2770 & 41.380 & 8.7 \\
\hline 8.6 & 23.256 & 3. 22253 & .34172 & 1. 50891 & 2783 & 41.861 & 8.6 \\
\hline 8.5 & 23.529 & 3. 25036 & .36955 & 1. 53674 & 2797 & 42.352 & 8.5 \\
\hline 8.4 & 23.810 & 3. 27833 & .39752 & 1. 56471 & 2810 & 42.858 & 8.4 \\
\hline 8.3 & 24.096 & 3. 30643 & .42562 & 1. 59281 & 2825 & 43.373 & 8.3 \\
\hline 8.2 & 24.390 & 3. 33468 & .45387 & 1. 62106 & 2839 & 43.902 & 8.2 \\
\hline 8.1 & 24.691 & 3. 36307 & .48226 & 1. 64945 & 2854 & 44.444 & 8.1 \\
\hline 8.0 & 25.000 & 3. 39161 & .51080 & 1. 67799 & 2869 & 45.000 & 8.0 \\
\hline 7.9 & 25.316 & 3.42030 & .53949 & 1. 70668 & 2886 & 45. 569 & 7.9 \\
\hline 7.8 & 25.641 & 3.44916 & .56835 & 1. 73554 & 2903 & 46.154 & 7.8 \\
\hline 7.7 & 25.974 & 3. 47819 & .59738 & 1. 76457 & 2919 & 46.753 & 7. 7 \\
\hline 7.6 & 26. 316 & 3. 50738 & .62657 & 1. 79376 & 2936 & $\begin{array}{l}70.750 \\
47.369\end{array}$ & 7.6 \\
\hline 7.5 & 26.667 & 3. 53674 & .65593 & 1. 82312 & 2954 & 48.001 & 7.5 \\
\hline 7.4 & 27.027 & 3. 56628 & .68547 & 1. 85266 & 2973 & 48. 649 & 7.4 \\
\hline 7.3 & 27.397 & 3. 59601 & .71520 & 1. 88239 & 2993 & 49.315 & 7.3 \\
\hline 7. 2 & 27.778 & 3. 62594 & .74513 & 1. 91232 & 3016 & 50.000 & 7. 2 \\
\hline 7.1 & 28.169 & 3.65610 & .77529 & 1. 94248 & 3040 & 50. 704 & 7.1 \\
\hline
\end{tabular}

TABLE 5. Vapor pressure of liquid $\mathrm{e}-\mathrm{H}_{2}$ (for interpolation)Continued

\begin{tabular}{|c|c|c|c|c|c|c|c|}
\hline$\frac{200}{T}$ & $T$ & \multicolumn{3}{|c|}{$\log _{10} P$} & $\Delta$ & $T$ & $\frac{360}{T}$ \\
\hline${ }^{\circ} K^{-}{ }_{1}$ & ${ }^{\circ} K$ & $\mathrm{~mm} \mathrm{Hg}$ & atm & psia & & ${ }^{\circ} R$ & ${ }^{\circ} R^{-1}$ \\
\hline 7.0 & 28.571 & 3. 68650 & 0.80569 & 1. 97288 & & 51.428 & 7.0 \\
\hline 6.9 & 28.986 & 3. 71716 & .83635 & 2. 00354 & $\begin{array}{l}3066 \\
3092\end{array}$ & 52. 175 & 6.9 \\
\hline 6.8 & 29.412 & 3. 74808 & .86727 & 2. 03446 & $\begin{array}{l}5092 \\
3119\end{array}$ & 52. 942 & 6.8 \\
\hline 6.7 & 29.851 & 3. 77927 & .89846 & 2. 06565 & 3146 & 53. 732 & 6.7 \\
\hline 6.6 & 30.303 & 3.81073 & .92992 & 2. 09711 & $\begin{array}{l}3146 \\
3173\end{array}$ & 54.545 & 6.6 \\
\hline 6.5 & 30. 769 & 3.84246 & .96165 & 2. 12884 & 3205 & 55. 384 & 6.5 \\
\hline 6.4 & 31.250 & 3.87451 & . 99370 & 2. 16089 & 3247 & 56. 250 & 6.4 \\
\hline 6.3 & 31.746 & 3. 90698 & 1. 02617 & 2. 19336 & $\begin{array}{l}52+1 \\
3303\end{array}$ & 57. 143 & 6.3 \\
\hline 6. 2 & 32. 258 & 3. 94001 & 1. 05920 & 2. 22639 & 3381 & 58.064 & 6. 2 \\
\hline 6.1 & 32.787 & 3. 97382 & 1. 09301 & 2. 26020 & 3487 & 59.017 & 6.1 \\
\hline 6. 0 & 33. 333 & (4. 00869) & (1. 12788) & (2. 29507) & 3629 & 60.000 & 6.0 \\
\hline 5.9 & 33.898 & (4.04498) & (1. 16417) & (2.33136) & & 61.016 & 5.9 \\
\hline
\end{tabular}

a Figures in parentheses are extrapolated values, to facilitate interpolation.

contains equations and tables giving what the authors judged to be the best values of the vapor pressures of $\mathrm{e}-\mathrm{H}_{2}, \mathrm{n}-\mathrm{H}_{2}, \mathrm{HD}$, e- $\mathrm{D}_{2}$, and $\mathrm{n}-\mathrm{D}_{2}$ up to about $1 \mathrm{~atm}$. Tables 5,6 , and 7 are consistent with the triple-point temperatures and pressures accepted by Woolley, Scott, and Brickwedde (WSB) [6, p. 453]. On the basis of the present data alone, slightly different triple points are obtained for $\mathrm{HD}$ and e- $\mathrm{D}_{2}$ (the triple point of $\mathrm{e}-\mathrm{H}_{2}$ was not measured), but the differences are so small that the WSB triple points have been retained. It has not, however, been possible to retain the same boiling points. Above the triple points, the WSB vapor pressures are higher than the present ones. This is shown by the three dotted curves in figure 2 labeled WSB equation. If expressed in terms of temperature, the deviations of the WSB equations for $\mathrm{e}-\mathrm{H}_{2}$ and $\mathrm{HD}$ from tables 5 and 6 are nearly the same, both equations being about 4 mdeg low at $19^{\circ} \mathrm{K}$ and 9 mdeg low at $22^{\circ} \mathrm{K}$. Such a discrepancy is probably due to a difference in temperature scales. In this connection it should be pointed out that most of the data on which the WSB equations are based were taken before this Bureau's temperature scale [9] below $90^{\circ} \mathrm{K}$ was established. They were for the most part expressed as differences of vapor-pressures of different modifications, as a function of the vapor pressure of a particular modification. Part of the WSB data, however, related the resistance of thermometer L6 or L3 to the vapor pressure of hydrogen (generally e- $\mathrm{H}_{2}$ ), and these were used to establish the temperatures of all the measurements. A discrepancy of up to 9 mdeg between the present temperature scale and that of the WSB equations seems large, but it unquestionably exists.

The deviation of the WSB equation for e- $\mathrm{D}_{2}$ from the present results increases much more rapidly than the deviations for e- $\mathrm{H}_{2}$ and $\mathrm{HD}$. However, the WSB data for e- $\mathrm{D}_{2}$ covered a range of less than 2 degrees $\mathrm{K}$ $\left(18.691^{\circ}\right.$ to $20.4^{\circ} \mathrm{K}$ ), whereas their measurements on liquid HD covered a range of nearly 4 degrees $\mathrm{K}$, and on liquid e- $\mathrm{H}_{2}$ of more than 6 degrees $\mathrm{K}$. It is not surprising that the equation based on the 
TABLE 6. Vapor pressure of liquid HD (for interpolation)

Interpolation with $200 / T$ as argument is more accurate and also more convenient than interpolation with $T$ as argument. Linear interpolation introduces no significant errors below about $25^{\circ} \mathrm{K}$. Between $25^{\circ}$ and $32^{\circ} \mathrm{K}$ linear interpolation is slightly inferior to higher-order interpolation, and above $32^{\circ} \mathrm{K}$ higher-order interpolation should be used if accurate values are required.

\begin{tabular}{|c|c|c|c|c|c|c|c|}
\hline \multirow{2}{*}{$\begin{array}{c}200 \\
T \\
T \\
\circ K^{-1} \\
12.1\end{array}$} & \multirow{2}{*}{$\begin{array}{c}T \\
\circ K \\
16.529\end{array}$} & \multicolumn{3}{|c|}{$\log _{10} P$} & \multirow{2}{*}{$\begin{array}{l}\Delta \\
295\end{array}$} & \multirow{2}{*}{$\begin{array}{c}T \\
\circ R \\
29.572\end{array}$} & \multirow{2}{*}{$\begin{array}{c}360 \\
{ }^{-} \\
\\
{ }^{\circ} R^{-1} \\
12.1\end{array}$} \\
\hline & & $\begin{array}{c}m m \mathrm{Hg} \\
(1.9516)\end{array}$ & $\begin{array}{l}\text { atm } \\
\text { a }(9.0708)\end{array}$ & $\begin{array}{c}p s i a \\
(0.2380)\end{array}$ & & & \\
\hline 12. 0 & 16. 667 & 1. 9811 & 9. 1003 & 2675 & & 30. 001 & 120 \\
\hline 11. & 16. 80 & & & $\begin{array}{r}2971 \\
.2968\end{array}$ & $\begin{array}{l}290 \\
297\end{array}$ & 30. 253 & 11.9 \\
\hline 11.8 & $\begin{array}{l}16.9 \\
17 .\end{array}$ & 2. 0404 & 9. 1596 & $\begin{array}{l}.3268 \\
3565\end{array}$ & 297 & $\begin{array}{l}30.508 \\
30.768\end{array}$ & 11.8 \\
\hline $\begin{array}{l}11.7 \\
11.6\end{array}$ & $\begin{array}{l}17.094 \\
17.241\end{array}$ & $\begin{array}{l}\text { 2. } 0701 \\
\text { 2. } 0998\end{array}$ & $\begin{array}{l}9.1893 \\
9.2190\end{array}$ & $\begin{array}{l}.3565 \\
.3862\end{array}$ & 297 & $\begin{array}{l}30.769 \\
31.034\end{array}$ & $\begin{array}{l}11.7 \\
11.6\end{array}$ \\
\hline 11.5 & 17.391 & 2. 1296 & 9. 2488 & .4160 & & 31.304 & 11.5 \\
\hline 11. 4 & 17.544 & 2. 1595 & 9. & 4459 & $\begin{array}{l}299 \\
209\end{array}$ & 31. 579 & $\begin{array}{l}11.5 \\
11.4\end{array}$ \\
\hline 11. 3 & 17. & 2. 1 & & 4757 & $\begin{array}{l}298 \\
299\end{array}$ & 31.858 & 11.3 \\
\hline 11. 2 & $\begin{array}{l}17.857 \\
18.01\end{array}$ & & & $\begin{array}{r}.5056 \\
5256\end{array}$ & 300 & 32. 143 & 11. 2 \\
\hline 11. 1 & 18.018 & 2. 2492 & 9. 3684 & .5356 & 300 & 32. 432 & 11.1 \\
\hline 11. 0 & 18. 182 & 2. 2792 & 9. 3984 & .5656 & & 32.728 & 11.0 \\
\hline 10. & 18. 349 & 2. 3093 & 9. 4285 & .5957 & $\begin{array}{l}301 \\
301\end{array}$ & 33. 028 & \\
\hline 10 & $\begin{array}{l}18.519 \\
18.692\end{array}$ & $\begin{array}{l}\text { 2. } 3394 \\
\text { 2.3695 }\end{array}$ & $\begin{array}{l}9.4887 \\
9.4589\end{array}$ & 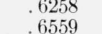 & 301 & $\begin{array}{l}33.334 \\
{ }_{3}^{3} 64\end{array}$ & 108 \\
\hline $\begin{array}{l}10 . \\
10 .\end{array}$ & $\begin{array}{l}18.692 \\
18.868\end{array}$ & $\begin{array}{l}\text { 2. 3695 } \\
\text { 2. } 3997\end{array}$ & $\begin{array}{l}\text { 9. } 4589 \\
9.4887\end{array}$ & $\begin{array}{l}.6559 \\
.6861\end{array}$ & 302 & $\begin{array}{l}33.646 \\
33.962\end{array}$ & $\begin{array}{l}10.7 \\
106\end{array}$ \\
\hline & & & 9.4808 & & 303 & 33.902 & 10.6 \\
\hline 10. 5 & 19. 048 & 2. 4300 & 9. 5492 & .7164 & 303 & 34. 286 & 10.5 \\
\hline $\begin{array}{l}10.4 \\
10.3\end{array}$ & $\begin{array}{l}19 . \\
19 .\end{array}$ & $\begin{array}{l}2.4 ! \\
2.4 !\end{array}$ & 9. & .746 & 304 & 34. & 10. 4 \\
\hline 10. 2 & 19. 608 & 2. 5211 & & 8075 & 304 & $\begin{array}{l}34 . \\
35 .\end{array}$ & $\begin{array}{l}10.3 \\
10.2\end{array}$ \\
\hline 10. & 19.8 & 2. 5516 & 08 & .8380 & 305 & 35. & $\begin{array}{l}10.2 \\
10.1\end{array}$ \\
\hline 10.0 & 20.000 & 2. 5821 & 9.7013 & .8685 & 305 & 36.000 & 10.0 \\
\hline 10. 0 & 20.000 & 2. 58207 & 9. 70126 & .86845 & & 36. & 10.0 \\
\hline 9. & 20. 202 & 2. 61264 & 9. 73183 & 89902 & $\begin{array}{l}305 \% \\
3063\end{array}$ & 36. 364 & 9.9 \\
\hline 9. & 20.4 & $\begin{array}{l}64327 \\
67397\end{array}$ & 9. 76246 & $\begin{array}{l}92965 \\
06035\end{array}$ & 3070 & $\begin{array}{l}36.734 \\
37\end{array}$ & 9. 8 \\
\hline 9. & $\begin{array}{l}20.619 \\
20.833\end{array}$ & $\begin{array}{l}2.67397 \\
\text { 2. } 70474\end{array}$ & $\begin{array}{l}9.79316 \\
9.82393\end{array}$ & $\begin{array}{l}96035 \\
99112\end{array}$ & 3077 & $\begin{array}{l}37.114 \\
37.499\end{array}$ & 9.7 \\
\hline & 20.800 & 2. 10484 & 9. 82393 & 99112 & 3084 & 37.499 & 9.6 \\
\hline $\begin{array}{l}9.5 \\
0.4\end{array}$ & 21. ! & 73558 & 9. 85477 & 1. 02195 & 3091 & $\begin{array}{l}37.895 \\
\text {. }\end{array}$ & 9. 5 \\
\hline $\begin{array}{l}9.4 \\
9.3\end{array}$ & & & 9 & 1.0 & 3097 & & 4 \\
\hline 9.2 & 21.739 & 2. 82 & & 1.11 & 3104 & $\begin{array}{l}38.709 \\
39.130\end{array}$ & $\begin{array}{l}9.3 \\
92\end{array}$ \\
\hline 9.1 & 21.978 & 2. 85961 & 9. 97880 & 1. 14599 & $\begin{array}{l}3111 \\
3119\end{array}$ & 39. 560 & 9.1 \\
\hline 9.0 & 22. 222 & 2. 89 & 0.00 & 1. & $31:$ & 4 & 9. 0 \\
\hline & $\begin{array}{l}\text { 22. } 472 \\
22\end{array}$ & & .04127 & & $\begin{array}{l}3128 \\
3137\end{array}$ & & \\
\hline 8. & 22.989 & $\begin{array}{l}2.95 \\
2.98 \\
\end{array}$ & $\begin{array}{l}072 \\
104\end{array}$ & $\begin{array}{l}1.23 \\
1.27\end{array}$ & 3148 & 40 & 87 \\
\hline 8.6 & 23. 256 & 3. 01649 & 13568 & 1. 30287 & $\begin{array}{l}3156 \\
3165\end{array}$ & $\begin{array}{l}41.380 \\
41.861\end{array}$ & $\begin{array}{l}8.7 \\
8.6\end{array}$ \\
\hline 8. & 23. 529 & 048 & 167 & 1. 33452 & & 42. & 8 \\
\hline 8. & 23.8 & & 199 & & & & 4 \\
\hline 8. & 24. 0 & & 230 & & 3199 & 43. & 8.3 \\
\hline 8. & 24. 390 & 3. 14 & 262 & 1.70 & & 43. 902 & 8. 2 \\
\hline 8.1 & 24. 691 & 3. 1758 & 29504 & 1. 46223 & $\begin{array}{l}5208 \\
3218\end{array}$ & 44. 444 & 8.1 \\
\hline $\begin{array}{l}8.0 \\
7.9\end{array}$ & $\begin{array}{l}25.0 \\
25 .\end{array}$ & 3. 26 & $\begin{array}{l}327 \\
359\end{array}$ & 1. & 3229 & 45. & \\
\hline 7.8 & $\begin{array}{l}25 . \\
25\end{array}$ & & .391 & $1.5 \mathrm{z}$ & & & \\
\hline 7.7 & 25.974 & 3. 3 & .424 & $\begin{array}{l}1.55 \\
1.59\end{array}$ & 3255 & 4 & 7. 8 \\
\hline 7.6 & 26.316 & 3. 33797 & 45716 & 1. 62435 & $\begin{array}{l}3267 \\
3281\end{array}$ & 47. 369 & 7.6 \\
\hline 7.5 & 26. 667 & 3. & 489 & 1. 65 & 3297 & 48. & 7.5 \\
\hline 7.4 & 27.9 & 3.4 & 52 & 1. & & & \\
\hline $\begin{array}{l}7.3 \\
7.2\end{array}$ & $\begin{array}{l}27.397 \\
27.78\end{array}$ & $\begin{array}{l}3.4 \\
3\end{array}$ & $\begin{array}{l}.556 \\
580\end{array}$ & & $\begin{array}{l}5311 \\
3326\end{array}$ & & \\
\hline 7.1 & $\begin{array}{l}28.169 \\
28.16\end{array}$ & $\begin{array}{l}\text { 3. } 47012 \\
\text { 3. } 50354\end{array}$ & $\begin{array}{l}.58931 \\
.62273\end{array}$ & $\begin{array}{l}1.75650 \\
1.78992\end{array}$ & 3342 & $\begin{array}{l}50.000 \\
50.704\end{array}$ & 7. 2 \\
\hline & & & & & 3358 & 50.604 & \\
\hline 6 & 28. & & .656 & $\begin{array}{l}1.8 \\
1.8\end{array}$ & 3375 & 51. & 7. 0 \\
\hline 6. & 29. & 3. 604 & .7240 & & & $\begin{array}{l}52 . \\
52 .\end{array}$ & 8 \\
\hline & & & .758 & 1.92 & $\begin{array}{l}3415 \\
3438\end{array}$ & 53. & 6. 7 \\
\hline & 30.303 & 3.67334 & .79253 & 1. 95972 & $\begin{array}{l}3438 \\
3461\end{array}$ & 54.545 & 6.6 \\
\hline 6.5 & 30.7 & 3 & & & & & \\
\hline & & & 86 & 2. 0 & $\begin{array}{l}3486 \\
3514\end{array}$ & & \\
\hline & 31.7 & & 897 & 2. 06 & & 57. & \\
\hline 6. & 3. & & .93 & & & & \\
\hline 6 & 32.78 & 3.84920 & .96839 & 2. 13558 & 3614 & 59.017 & \\
\hline 6. & $\begin{array}{l}\text { 33. } 333 \\
3389\end{array}$ & $\begin{array}{l}3.88534 \\
2\end{array}$ & 1. 0 & 2. & & 60. & 6. 0 \\
\hline & $\begin{array}{l}33.8 \\
34.4\end{array}$ & $\begin{array}{l}3,92 \\
3,95\end{array}$ & & & $\begin{array}{l}3004 \\
3700\end{array}$ & & 5 \\
\hline & 35.0 & 3. 99 & $\begin{array}{l}\text { 1. } 07807 \\
1.11564\end{array}$ & $\begin{array}{l}2.24 \\
2.28\end{array}$ & 3757 & $\begin{array}{l}62 . \\
63 .\end{array}$ & $\begin{array}{l}5.8 \\
5.7\end{array}$ \\
\hline & 35.714 & 4. 03474 & 1. 15393 & 2. 32112 & $\begin{array}{l}3829 \\
3919\end{array}$ & $\begin{array}{l}0.1 .158 \\
64.285\end{array}$ & $\begin{array}{l}5 . \\
5 .\end{array}$ \\
\hline $\begin{array}{l}5.5 \\
5.4\end{array}$ & $\begin{array}{l}36.364 \\
37.037\end{array}$ & $\begin{array}{l}\text { (4. } 07393) \\
(4.11424)\end{array}$ & $\begin{array}{l}(1.19312) \\
(1.23343)\end{array}$ & $\begin{array}{l}(2.36031) \\
(2.40062)\end{array}$ & 4031 & $\begin{array}{l}65.455 \\
66.667\end{array}$ & 5. 5 \\
\hline
\end{tabular}

a Figures in parentheses are extrapolated values, to facilitate interpolation.
TABLE 7. Vapor pressure of liquid e- $\mathrm{D}_{2}$ (for interpolation)

Interpolation with $200 / T$ as argument is more accurate and also more convenient than interpolation with $T$ as argument. Linear interpolation introduces no significant errors below about $27^{\circ} \mathrm{K}$. Between $27^{\circ}$ and $33.5^{\circ} \mathrm{K}$ linear interpolation is slightly inferior to higher-order interpolation, and above $33.5^{\circ} \mathrm{K}$ higherorder interpolation should be used if accurate values are required.

\begin{tabular}{|c|c|c|c|c|c|c|c|}
\hline \multirow{2}{*}{$\begin{array}{l}\frac{200}{T} \\
{ }^{\circ} K^{-1}\end{array}$} & \multirow{2}{*}{$\begin{array}{c}T \\
{ }^{\circ} K\end{array}$} & \multicolumn{3}{|c|}{$\log _{10} P$} & \multirow[t]{2}{*}{$\Delta$} & \multirow{2}{*}{$\frac{T}{{ }^{\circ} R}$} & \multirow{2}{*}{$\begin{array}{c}\frac{360}{T} \\
{ }^{\circ} R^{-1}\end{array}$} \\
\hline & & $m m \mathrm{Hg}$ & atm & psia & & & \\
\hline 10.8 & 18. 519 & $(2.0753)$ & (9. 1945) & $(0.3617)$ & & 33. 334 & 10.8 \\
\hline $\begin{array}{l}10.7 \\
10.6\end{array}$ & $\begin{array}{l}18.692 \\
18.868\end{array}$ & $\begin{array}{l}21090 \\
2.1428\end{array}$ & $\begin{array}{l}\text { 9. } 2282 \\
\text { 9. } 2620\end{array}$ & $\begin{array}{r}.3954 \\
.4292\end{array}$ & 338 & $\begin{array}{l}33.646 \\
33.962\end{array}$ & $\begin{array}{l}10.7 \\
10.6\end{array}$ \\
\hline & & & & & & & \\
\hline $\begin{array}{l}10.5 \\
10.4\end{array}$ & $\begin{array}{l}19.048 \\
19.231\end{array}$ & $\begin{array}{l}2.1766 \\
2.2105\end{array}$ & $\begin{array}{l}9.2958 \\
9.3297\end{array}$ & $\begin{array}{r}.4630 \\
.4969\end{array}$ & 339 & $\begin{array}{l}34.286 \\
34616\end{array}$ & $\begin{array}{l}10.5 \\
10.4\end{array}$ \\
\hline 10.3 & 19.417 & 2. 2445 & 9. 3637 & 5309 & $\begin{array}{l}340 \\
341\end{array}$ & 34.951 & 10.3 \\
\hline 10. 2 & 19.608 & 2. 2786 & 9. 3978 & .5650 & $\begin{array}{l}541 \\
341 \\
341\end{array}$ & 35. 294 & 10. 2 \\
\hline 10.1 & 19.802 & 2.3127 & 9. 4319 & .5991 & 342 & 35.644 & 10.1 \\
\hline 10.0 & 20.000 & 2. 3469 & 9. 4661 & 6333 & & 36.000 & 10.0 \\
\hline 9.9 & 20.202 & 2. 3811 & 9. 5003 & .6675 & $\begin{array}{l}342 \\
344\end{array}$ & 36. 364 & 9.9 \\
\hline 9.8 & 20.408 & 2.4155 & 9. 5347 & .7019 & 344 & 36. 734 & 9.8 \\
\hline 9.7 & 20.619 & 2. 4499 & 9. 5691 & .7363 & 344 & 37. 114 & 9.7 \\
\hline 9.6 & 20.833 & 2. 4843 & 9. 6035 & .7707 & 346 & 37. 499 & 9.6 \\
\hline 9.5 & 21. 053 & 2. 5189 & 9. 6381 & .8053 & & 37.895 & 9.5 \\
\hline 9.5 & 21.053 & 2. 51889 & 9. 63808 & .80527 & 3461 & 37.895 & 9.5 \\
\hline 9.4 & 21. 277 & 2. 55350 & 9. 67269 & .83988 & $\begin{array}{l}5401 \\
3464\end{array}$ & 38. 299 & 9.4 \\
\hline 9.3 & 21. 505 & 2. 58814 & 9. 70733 & .87452 & $\begin{array}{l}3404 \\
3468\end{array}$ & 38.709 & 9.3 \\
\hline 9. 2 & $\begin{array}{l}\text { 21. } 739 \\
01\end{array}$ & 2. 62282 & 9. 74201 & . 90920 & $\begin{array}{l}3408 \\
3472\end{array}$ & 39. 130 & 9. 2 \\
\hline 9.1 & 21.978 & 2. 65754 & 9. 77673 & .94392 & $\begin{array}{l}3472 \\
3476\end{array}$ & 39.560 & 9.1 \\
\hline 9.0 & 22. 222 & 2. 69230 & 9. 81149 & 97868 & & 40.000 & 9. 0 \\
\hline 8.9 & 22.472 & 2. 72713 & 9. 84632 & 1. 01351 & $\begin{array}{l}5485 \\
3490\end{array}$ & 40.450 & 8.9 \\
\hline 8. 8 & 22.727 & 2. 76203 & 9. 88122 & 1. 04841 & $\begin{array}{l}\begin{array}{r}3490 \\
3497\end{array}\end{array}$ & 40. 909 & 8.8 \\
\hline 8.7 & 22. 989 & 2. 79700 & 9. 91619 & 1. 08338 & & 41.380 & 8.7 \\
\hline 8.6 & 23. 256 & 2. 83204 & 9. 95123 & 1. 11842 & $\begin{array}{l}3504 \\
3512\end{array}$ & 41.861 & 8.6 \\
\hline 8.5 & 23. 529 & 2. 86716 & 9. 98635 & 1. 15354 & 3519 & 42.352 & 8.5 \\
\hline 8.4 & 23.810 & 2. 90235 & 0.02154 & 1. 18873 & 3527 & 42.857 & 8.4 \\
\hline 8.3 & 24. 096 & 2. 93762 & .05681 & 1. 22400 & 3536 & 43.373 & 8.3 \\
\hline 8.2 & 24.390 & 2. 97298 & .09217 & 1. 25936 & $\begin{array}{l}5000 \\
3546\end{array}$ & 43. 902 & 8. 2 \\
\hline 8.1 & 24.691 & 3. 00844 & .12763 & 1. 29482 & $\begin{array}{l}3546 \\
3555\end{array}$ & 44.444 & 8.1 \\
\hline 8.0 & 25.000 & 3. 04399 & .16318 & 1. 33037 & & 45. 000 & 8.0 \\
\hline 7.9 & 25. 316 & 3. 07963 & .19882 & 1. 36601 & $\begin{array}{l}5504 \\
3574\end{array}$ & 45. 569 & 7. 9 \\
\hline 7.8 & $\begin{array}{l}25.641 \\
25.974\end{array}$ & $\begin{array}{l}3.11537 \\
3\end{array}$ & .23456 & 1. 40175 & $\begin{array}{l}3585 \\
3584\end{array}$ & $\begin{array}{l}46.154 \\
46.75\end{array}$ & 7.8 \\
\hline 7.6 & $\begin{array}{l}25.974 \\
26.316\end{array}$ & $\begin{array}{l}3.15122 \\
3.18718\end{array}$ & $\begin{array}{l}.27041 \\
.30637\end{array}$ & $\begin{array}{l}\text { 1. } 43760 \\
1.47356\end{array}$ & $\begin{array}{l}3596 \\
3607\end{array}$ & $\begin{array}{l}46.753 \\
47.369\end{array}$ & $\begin{array}{l}7.7 \\
7.6\end{array}$ \\
\hline 7.5 & 26.667 & 3. 22325 & .34244 & 1. 50963 & & 48.001 & 7.5 \\
\hline 7.4 & 27. 027 & 3. 25941 & .37860 & 1. 54579 & $\begin{array}{l}5010 \\
3626\end{array}$ & 48. 649 & 7.4 \\
\hline 7.3 & 27. 397 & 3. 29567 & . 41486 & 1. 58205 & $\begin{array}{l}5020 \\
3636\end{array}$ & 49.315 & 7.3 \\
\hline 7.2 2 & 27.778 & 3. 33203 & .45122 & 1. 61841 & $\begin{array}{l}5030 \\
3648\end{array}$ & 50. 000 & 7. 2 \\
\hline 7.1 & 28. 169 & 3. 36851 & .48770 & 1. 65489 & $\begin{array}{l}5070 \\
3662\end{array}$ & 50.704 & 7.1 \\
\hline 7.0 & 28. 571 & 3. 40513 & .52432 & 1. 69151 & 3676 & 51. 428 & 7. 0 \\
\hline 6.9 & 28. 986 & 3. 44189 & .56108 & 1. 72827 & $\begin{array}{l}3690 \\
3690\end{array}$ & 52.175 & 6.9 \\
\hline 6.8 & 29.412 & 3. 47879 & .59798 & 1. 76517 & $\begin{array}{l}3706 \\
3700\end{array}$ & 52.942 & 6.8 \\
\hline 6.7 & 29.851 & 3. 51585 & .63504 & 1. 80223 & 3725 & 53.732 & 6.7 \\
\hline 6.6 & 30.303 & 3. 55310 & .67229 & 1. 83948 & $\begin{array}{l}3745 \\
3745\end{array}$ & 54.545 & 6.6 \\
\hline 6.5 & 30.769 & 3. 59055 & .70974 & 1. 87693 & & 55. 384 & 6.5 \\
\hline 6.4 & 31.250 & 3. 62820 & .74739 & 1. 91458 & $\begin{array}{l}5300 \\
3785\end{array}$ & 56.250 & 6.4 \\
\hline $\begin{array}{l}6.3 \\
6.2\end{array}$ & $\begin{array}{l}31.746 \\
32.258\end{array}$ & $\begin{array}{l}3.66605 \\
3\end{array}$ & .78524 & 1. 95243 & 3807 & $\begin{array}{l}57.143 \\
58\end{array}$ & 6. 3 \\
\hline 6. 2 & 32. 258 & 3. 70412 & 82331 & 1. 99050 & 3831 & 58.064 & 6. 2 \\
\hline 6. & 32.787 & 3. 74243 & .86162 & 2. 02881 & 3861 & 59.017 & 6.1 \\
\hline 6. 0 & 33. 333 & 3. 78104 & . 90023 & 2. 06742 & & 60.000 & 6.0 \\
\hline 5. 9 & 33. 898 & 3. 81996 & 93915 & 2. 10634 & $\begin{array}{l}3892 \\
3925\end{array}$ & 61.016 & 5. 9 \\
\hline 5.8 & 34.483 & 3. 85921 & .97840 & 2. 14559 & $\begin{array}{l}0920 \\
3961\end{array}$ & 62.069 & 5.8 \\
\hline 5.7 & 35. 088 & 3. 89882 & 1. 01801 & 2. 18520 & $\begin{array}{l}3961 \\
3998\end{array}$ & 63.158 & 5.7 \\
\hline 5.6 & 35.714 & 3. 93880 & 1. 05799 & 2. 22518 & $\begin{array}{l}3998 \\
4038\end{array}$ & 64.285 & 5.6 \\
\hline 5.5 & 36. 364 & 3. 97918 & 1. 09837 & 2. 26556 & 4085 & 65.455 & 5.5 \\
\hline 5.4 & 37. 037 & 4. 02003 & 1. 13922 & 2. 30641 & $\begin{array}{l}4080 \\
4151\end{array}$ & 66.667 & 5.4 \\
\hline 5.3 & 37.736 & 4. 06154 & 1. 18073 & 2. 34792 & $\begin{array}{l}7101 \\
4268\end{array}$ & 67.925 & 5.3 \\
\hline 5. 2 & 38. 462 & (4. 10422) & (1. 22341) & (2. 39060) & $\begin{array}{l}4208 \\
4437\end{array}$ & 69.232 & 5. 2 \\
\hline 5.1 & 39. 216 & $(4.14859)$ & (1. 26778) & (2. 43497) & 4437 & 70.589 & 5.1 \\
\hline
\end{tabular}

shortest range of experimental data is the least satisfactory for extrapolation.

There appear to be no other data at higher pressures for $\mathrm{e}-\mathrm{H}_{2}, \mathrm{HD}$, or $\mathrm{e}-\mathrm{D}_{2}$. There are, however, data for $n-\mathrm{H}_{2}$ and $n-\mathrm{D}_{2}$ with which a comparison can be made. Figure 3 show such a comparison. The upper diagram refers to $\mathrm{H}_{2}$, the base line being table 5 , which represents our results for e- $\mathrm{H}_{2}$. It will be 
TABLE 8. Vapor pressures of liquid $\mathrm{e}-\mathrm{H}_{2}, \mathrm{HD}$, and $\mathrm{e}-\mathrm{D}_{2}$ at intervals of 1 degree $K$

\begin{tabular}{|c|c|c|c|c|c|c|c|c|c|c|}
\hline $\mathrm{T}$ & \multicolumn{3}{|c|}{$\begin{array}{cc}20.4^{\circ} \mathrm{K} & \mathrm{e}-\mathrm{H}_{2} \\
(0.21 \% & \left.\mathrm{O}-\mathrm{H}_{2}\right) \\
\mathrm{P}^{\mathrm{O}}\end{array}$} & \multicolumn{3}{|c|}{$\begin{array}{c}\text { Hydrogen deuteride, } \\
\text { HD } \\
\mathrm{P}\end{array}$} & \multicolumn{3}{|c|}{ 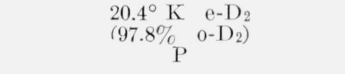 } & $\mathrm{T}$ \\
\hline \multicolumn{11}{|c|}{ Solid } \\
\hline $\begin{array}{c}\circ \mathrm{K} \\
10 \\
11 \\
12 \\
13 \\
14\end{array}$ & $\begin{array}{c}m m \mathrm{Hg} \\
1.93 \\
5.62 \\
13.9 \\
30.2 \\
-. . .\end{array}$ & $\begin{array}{l}\text { atm } \\
0.00254 \\
.00739 \\
.0183 \\
.0397 \\
\end{array}$ & $\begin{array}{c}p s i a \\
0.0373 \\
.109 \\
.269 \\
.584 \\
\end{array}$ & $\begin{array}{c}m m \mathrm{Hg} \\
0.28 \\
.99 \\
2.94 \\
7.46 \\
16.8\end{array}$ & $\begin{array}{c}\text { atm } \\
0.00037 \\
.00130 \\
.00387 \\
.00982 \\
.0221\end{array}$ & $\begin{array}{c}\text { psia } \\
0.0054 \\
.0191 \\
.0569 \\
.144 \\
.325\end{array}$ & $\begin{array}{c}m m \mathrm{Hg} \\
0.05 \\
.21 \\
.75 \\
2.20 \\
5.57\end{array}$ & $\begin{array}{c}\text { atm } \\
0.00007 \\
.00028 \\
.00099 \\
.00289 \\
.00733\end{array}$ & $\begin{array}{c}p s i a \\
0.0010 \\
.0041 \\
.0145 \\
.0425 \\
.108\end{array}$ & $\begin{array}{l}{ }^{\circ} \mathrm{R} \\
18.0 \\
19.8 \\
21.6 \\
23.4 \\
25.2\end{array}$ \\
\hline $\begin{array}{l}15 \\
16 \\
17 \\
18\end{array}$ & n. & (n) & n & $\begin{array}{l}34.4 \\
65.2 \\
\cdots\end{array}$ & $\begin{array}{l}.0453 \\
.0858 \\
\end{array}$ & 1. 261 & $\begin{array}{l}12.6 \\
26.0 \\
49.6 \\
88.7\end{array}$ & $\begin{array}{l}.0166 \\
.0342 \\
.0653 \\
.1167\end{array}$ & $\begin{array}{r}.244 \\
.503 \\
.959 \\
1.715\end{array}$ & $\begin{array}{l}27.0 \\
28.8 \\
30.6 \\
32.4\end{array}$ \\
\hline \multicolumn{11}{|c|}{ Liquid } \\
\hline 14 & 58.8 & 0.0774 & 1.137 & ...... & 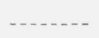 & -. & & & & 25.2 \\
\hline $\begin{array}{l}15 \\
16 \\
17 \\
18 \\
19\end{array}$ & $\begin{array}{l}100.3 \\
161.1 \\
246.0 \\
360.3 \\
509.5\end{array}$ & $\begin{array}{l}.1320 \\
.2120 \\
.3237 \\
.4741 \\
.6704\end{array}$ & $\begin{array}{l}\text { 1. } 939 \\
\text { 3. } 115 \\
4.757 \\
6.967 \\
9.852\end{array}$ & $\begin{array}{l}112.4 \\
176.2 \\
264.2\end{array}$ & $\begin{array}{r}0.1479 \\
.2318 \\
.3476\end{array}$ & $\begin{array}{l}2.173 \\
\text { 3. } 407 \\
5.109\end{array}$ & 147.1 & 0.1936 & 2.844 & $\begin{array}{l}27.0 \\
28.8 \\
30.6 \\
32.4 \\
34.2\end{array}$ \\
\hline $\begin{array}{l}20 \\
21 \\
22 \\
23 \\
24\end{array}$ & $\begin{array}{r}699.2 \\
935.3 \\
1223.7 \\
1570.5 \\
1981.8\end{array}$ & $\begin{array}{l}.9200 \\
\text { 1. } 2307 \\
\text { 1. } 6101 \\
\text { 2. } 0664 \\
\text { 2. } 6076\end{array}$ & $\begin{array}{l}13.520 \\
18.086 \\
23.663 \\
30.369 \\
38.322\end{array}$ & $\begin{array}{r}382.0 \\
534.9 \\
728.5 \\
969.0 \\
1262.3\end{array}$ & $\begin{array}{r}.5026 \\
.7038 \\
.9586 \\
1.2750 \\
1.6609\end{array}$ & $\begin{array}{r}7.387 \\
10.343 \\
14.087 \\
18.737 \\
24.409\end{array}$ & $\begin{array}{l}222.3 \\
324.1 \\
457.8 \\
628.8 \\
843.1\end{array}$ & $\begin{array}{r}.2925 \\
.4264 \\
.6024 \\
.8274 \\
1.1093\end{array}$ & $\begin{array}{r}4.299 \\
6.267 \\
8.852 \\
12.159 \\
16.303\end{array}$ & $\begin{array}{l}36.0 \\
37.8 \\
39.6 \\
41.4 \\
43.2\end{array}$ \\
\hline $\begin{array}{l}25 \\
26 \\
27 \\
28 \\
29\end{array}$ & $\begin{array}{l}2463.8 \\
3022.9 \\
3665.1 \\
4396.8 \\
5227\end{array}$ & $\begin{array}{l}3.2418 \\
3.9775 \\
4.8225 \\
5.785 \\
6.877\end{array}$ & $\begin{array}{r}47.642 \\
58.45 \\
70.87 \\
85.02 \\
101.07\end{array}$ & $\begin{array}{l}1614.5 \\
2031.5 \\
2519.4 \\
3084.6 \\
3732.8\end{array}$ & $\begin{array}{l}2.1243 \\
2.6730 \\
\text { 3. } 3150 \\
4.0587 \\
4.9116\end{array}$ & $\begin{array}{l}31.219 \\
39.283 \\
48.717 \\
59.65 \\
72.18\end{array}$ & $\begin{array}{l}1106.6 \\
1425.6 \\
1806.1 \\
2253.5 \\
2774.3\end{array}$ & $\begin{array}{l}1.4561 \\
1.8758 \\
2.3764 \\
2.9651 \\
3.6504\end{array}$ & $\begin{array}{l}21.398 \\
27.567 \\
34.924 \\
43.576 \\
53.65\end{array}$ & $\begin{array}{l}45.0 \\
46.8 \\
48.6 \\
50.4 \\
52.2\end{array}$ \\
\hline $\begin{array}{l}30 \\
31 \\
32 \\
33 \\
34\end{array}$ & $\begin{array}{r}6162 \\
7210 \\
8383 \\
\end{array}$ & $\begin{array}{r}8.108 \\
9.486 \\
11.031 \\
\end{array}$ & $\begin{array}{l}119.16 \\
139.41 \\
162.10 \\
\end{array}$ & $\begin{array}{l}4470.8 \\
5306 \\
6246 \\
7301 \\
8480\end{array}$ & $\begin{array}{r}5.883 \\
6.982 \\
8.219 \\
9.607 \\
11.157\end{array}$ & $\begin{array}{r}86.45 \\
102.61 \\
120.79 \\
141.18 \\
163.97\end{array}$ & $\begin{array}{l}3374.7 \\
4062.0 \\
4842.4 \\
5723 \\
6712\end{array}$ & $\begin{array}{l}4.4404 \\
5.345 \\
6.372 \\
7.530 \\
8.832\end{array}$ & $\begin{array}{r}65.26 \\
78.55 \\
93.64 \\
110.66 \\
129.79\end{array}$ & $\begin{array}{l}54.0 \\
55.8 \\
57.6 \\
59.4 \\
61.2\end{array}$ \\
\hline $\begin{array}{l}35 \\
36 \\
37 \\
38\end{array}$ & $\ldots$ & - & - & 9796 & 12.889 & 189.42 & $\begin{array}{r}7819 \\
9051 \\
10418 \\
11943\end{array}$ & $\begin{array}{l}10.288 \\
11.909 \\
13.708 \\
15.714\end{array}$ & $\begin{array}{l}151.19 \\
175.02 \\
201.45 \\
230.94\end{array}$ & $\begin{array}{l}63.0 \\
64.8 \\
66.6 \\
68.4\end{array}$ \\
\hline
\end{tabular}

TABLE 9. Triple points and boiling points of $\mathrm{e}-\mathrm{H}_{2}, \mathrm{HD}$, and $\mathrm{e}-\mathrm{D}_{2}$

The triple points are the same as those of Woolley, Scott, and Brickwedde [6]

\begin{tabular}{|c|c|c|c|c|c|c|c|}
\hline \multirow{2}{*}{$\begin{array}{l}\text { Modifi- } \\
\text { cation }\end{array}$} & \multicolumn{5}{|c|}{ Triple point } & \multirow{2}{*}{\multicolumn{2}{|c|}{$\begin{array}{c}\text { Normal } \\
\text { boiling point, } \\
T\end{array}$}} \\
\hline & $T$ & & $P$ & & $T$ & & \\
\hline $\begin{array}{l}\mathrm{e}-\mathrm{H}_{2} \\
\mathrm{HD} \\
\mathrm{e}-\mathrm{D}_{2}\end{array}$ & $\begin{array}{l}\circ K \\
\text { 13. } 81_{3} \\
16.60_{4} \\
18.69_{1}\end{array}$ & $\begin{array}{c}m m \mathrm{Hg} \\
52.8 \\
92.8 \\
128.5\end{array}$ & $\begin{array}{r}\text { atm } \\
0.0695 \\
.1221 \\
.1691\end{array}$ & $\begin{array}{l}\text { psia } \\
\text { 1. } 02 \\
\text { 1. } 79 \\
\text { 2. } 48\end{array}$ & $\begin{array}{c}\circ R \\
24.86_{3} \\
29.88_{7} \\
33.64_{4}\end{array}$ & $\begin{array}{r}\circ K \\
20.278 \\
22.14_{3} \\
23.637\end{array}$ & $\begin{array}{l}\circ R \\
36.500 \\
39.857 \\
42.457\end{array}$ \\
\hline
\end{tabular}

seen from the auxiliary ordinate scale at the righthand side of the graph that from the critical point down to the boiling point the vapor pressure of $n-\mathrm{H}_{2}$ is about 3.5 percent lower than that of $\mathrm{e}-\mathrm{H}_{2}$, but that at lower temperatures the percentage difference increases. This is shown by the dotted line that represents the WSB equation for $n-H_{2}$. The data plotted include those of Cath and Onnes [12]. These are chiefly of historical interest, since the measurements were reported in 1917 before the existence of the ortho and para forms was recognized. The other data are all very recent, being those of Grilly [5], and of White, Friedman, and Johnston [3, 13]. The lower diagram refers to $\mathrm{D}_{2}$, the base line being table 7 , which represents our results for e- $\mathrm{D}_{2}$. The data plotted in this graph are those of Grilly [5], and those of the present research given in table 4 . In both researches the material was uncatalyzed and was assumed therefore to be $n-D_{2}$. In confirmation of this assumption it may be noted that at $21^{\circ} \mathrm{K}$ $\left[P\left(\mathrm{e}-\mathrm{D}_{2}\right)-P\left(\mathrm{n}-\mathrm{D}_{2}\right)\right]$ computed from figure 3 is roughly equal to the same quantity computed from the appropriate WSB vapor-pressure equations. The lack of complete agreement could be due to partial conversion of the $n-D_{2}$, but is just as likely to be due to incipient failure of the equations at the ends of their ranges. Above the boiling point, the vapor pressure of $n-D_{2}$ is about 0.5 percent lower than that of $\mathrm{e}-\mathrm{D}_{2}$. At lower temperatures the percentage difference increases.

It is possible to use table 5 for calculations involving $\mathrm{n}-\mathrm{H}_{2}$ by drawing a smooth curve to represent the values of $\dot{P}\left(\mathrm{n}-\mathrm{H}_{2}\right) / P($ table 5$)$. In a similar way table 7 may of course be used for calculations involving $\mathrm{n}-\mathrm{D}_{2}$.

\subsection{Accuracy}

The discussion of the accuracy of pressure measurements given in reference [8] is applicable to the present results. The uncertainties in the temperature scale are somewhat greater here than in the 
measurements on oxygen, but since the same temperature scale was used for all the measurements, the relative accuracy of the temperatures is quite high. The $\mathrm{e}-\mathrm{H}_{2}$ and $\mathrm{e}-\mathrm{D}_{2}$ tables are more accurate than the HD table because of the decomposition of the latter during the measurements. The pressures given for $\mathrm{e}-\mathrm{H}_{2}$ and $\mathrm{e}-\mathrm{D}_{2}$ are believed to be accurate to 0.2 or $0.3 \mathrm{~mm} \mathrm{Hg}$ up to about $1 \mathrm{~atm}$. Above 1 atm the uncertainty gradually increases, reaching perhaps $\pm 8 \mathrm{~mm} \mathrm{Hg}$ near the critical points. For HD the pressures up to 1 atm are probably equally accurate, but above 1 atm the uncertainty is larger, gradually increasing to perhaps $\pm 15 \mathrm{~mm} \mathrm{Hg}$ near the critical point. Uncertainty in the temperature scale is perhaps $\pm 20 \mathrm{~m}$ deg.

\section{Dew-Point Pressures of Mixtures}

Since no information on the vapor pressures of mixtures of $\mathrm{H}_{2}, \mathrm{HD}$, and $\mathrm{D}_{2}$ appears in the literature, it was thought worth while to determine approximately how far such mixtures depart from ideal solution behavior, even to the limited precision and within the limited range of temperature and composition allowed by the time available for this work. Experimental dew-point pressures of mixtures were compared with those predicted by the law of ideal solutions and discrepancies greater than the experimental error were found. Significant deviations from ideality in mixtures of ortho- and para- $\mathrm{H}_{2}$ have been previously observed by Woolley, Scott and Brickwedde [6, p. 454].

\subsection{The Law of Ideal Solutions}

The applicability of the law of ideal solutions to a liquid mixture at a given temperature can be tested by measuring the dew-point pressure, at the given temperature, of a gaseous mixture of the same components in a known composition. In the derivation of the appropriate equation, the following symbols will be used: $x_{i}$, mole fraction of the $i$ th component in the liquid phase; $y_{i}$, mole fraction of the $i$ th component in the vapor phase; $P_{o i}$, vapor pressure of the $i$ th component in pure form; $P_{v}$, total pressure of the vapor in equilibrium with the liquid mixture; $Z_{i}(P)$, value of $P V / R T$ for the $i$ th component in pure form at the pressure $P$, all at the same temperature. The law of ideal solutions states that in the vapor that is in equilibrium with an ideal liquid solution the partial pressure of the $i$ th component is equal to $x_{i} P_{o i}$. Assuming that this partial pressure is also equal to $y_{i} P_{v}$, we have

$$
x_{i} P_{o i}=y_{i} P_{v} \text {. }
$$

Equating the sum of the $y$ 's to unity yields the expression for the vapor pressure of an ideal solution;

$$
P_{v}=\Sigma x_{i} P_{o i} \text {. }
$$

In the dew-point experiment the $y$ 's rather than the $x$ 's are known, and therefore the proper form of the expression is that obtained by equating the sum of the $x$ 's to unity;

$$
1 / P_{v}=\Sigma y_{i} / P_{o i}
$$

A more rigorous expression of the law would result from using fugacities in place of pressures in eq 1 , but this refinement seems to have a negligible effect on $P_{v}$ in the present instances. In an approximation sufficiently good to show the order of magnitude of the effect of using fugacities [see 14, p. 197 to 199, 221 to 227], eq 1 becomes

$$
x_{i} P_{o i} Z_{i}\left(P_{o i}\right)=y_{i} P_{v} Z_{i}\left(P_{v}\right) .
$$

By this substitution, eq 3 is changed to

$$
1 / P_{v}=\Sigma y_{i} Z_{i}\left(P_{v}\right) / P_{o i} Z_{i}\left(P_{o i}\right) \text {. }
$$

In order to evaluate eq 5 we take values of $Z(P)$ for $\mathrm{H}_{2}$ and $\mathrm{D}_{2}$ from reference [6] and, in the absence of experiemental values for $\mathrm{HD}$, assume $Z(P)$ for $\mathrm{HD}$ equal to the mean of the values for $\mathrm{H}_{2}$ and $\mathrm{D}_{2}$. Values of $P_{v}$ calculated from eq 5 differ from those calculated from eq 3 by only about $0.2 \mathrm{~mm} \mathrm{Hg}$, which is small compared to the experimental deviations from ideality.

\subsection{Apparatus and Method}

The equipment consisted of a 3-liter gas reservoir (which also served as a mixing bulb), a $140-\mathrm{cm}^{3}$ temperature-controlled chamber, and a combination mercury pump and mercury manometer. There were three functions for the latter, first to measure the pressure in the reservoir during mixing, second to transfer measured quantities of gas from the reservoir to the constant-temperature chamber, and third to measure the pressure in the chamber. A vacuum-type adiabatic calorimeter that had been previously constructed at this laboratory by $R$. B. Scott [15] was used as the isothermal chamber. The connection of these components is shown in figure 4.

A run proceeded as follows. One component of the mixture to be tested was admitted to the reservoir (at room temperature), and the reservoir pressure was measured. Then the second component was admitted and the pressure again measured, the mercury level in the manometer being adjusted to keep the reservoir volume constant. The composition of the mixture was deduced from these pressures taking into consideration the slight isotopic impurities in the individual components as determined by mass-spectrometer analysis. (There were traces of $\mathrm{HD}$ in the $\mathrm{D}_{2}$ samples and of $\mathrm{H}_{2}$ and $\mathrm{D}_{2}$ in the $\mathrm{HD}$ samples.) The gaseous mixture was allowed to flow into the chamber until the chamber pressure was about $30 \mathrm{~mm} \mathrm{Hg}$ less than the expected dew-point pressure. A selected volume of the pump-manometer was then filled with gas from the reservoir, the quantity being determined by the pressure difference in the pump before and after filling. This 


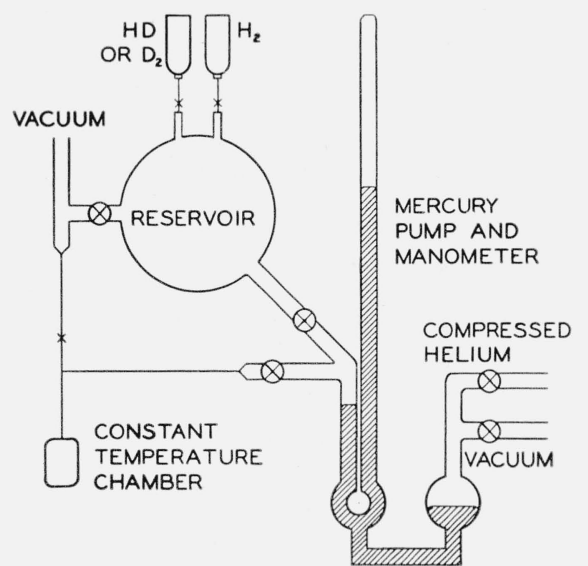

Figure 4. Schematic drawing of the apparatus used in the dew-point pressure measurements.

quantity was then pumped into the chamber, and the chamber pressure was remeasured. Before each reading of the chamber pressure the chamber was brought to the temperature of the run and the mercury was brought to a selected level. Each reading was repeated after several minutes to make sure that equilibrium had been attained. By repeating this pumping operation a series of points of chamber pressure versus added quantity of mixture was obtained. Temperatures for all points in a run were equal within about $0.00_{3} \mathrm{deg} K$ to the average for the run. The thermometer used was L18, which has been calibrated against the Bureau's temperature scale [9], and which after these experiments checked satisfactorily at the ice point.

\subsection{Results}

Figure 5 is an example of a curve obtained in the manner described above. The dew-point pressure is taken to be the pressure at the intersection of the extrapolations of the two straight-line portions of the curve. Although the values of the abscissas are in error by that quantity of added material that went into the uncooled dead space of the apparatus (about $2 \%$ of the total quantity), the error is linear in terms of the pressure and hence has no effect upon the ordinate of the point of intersection. Manometer readings must be multiplied by 0.995 to convert to standard millimeters of mercury.

The results of seven runs are presented in table 10 . Calculated pressures are taken from eq 3, using vapor pressures from reference [6, p. 454]. The ortho-para compositions are assumed to correspond to equilibrium at high temperature since no catalyst was used. This assumption is supported by the single-component dew-point pressures (runs E and $\mathrm{H})$ observed with this apparatus. If these two pressures were plotted on the graphs of figure 3 they would fall within 0.0015 (in units of $\Delta \log _{10} P$ ) of the WSB curves for $n-D_{2}$ and $n-H_{2}$, respectively. The tabular entry $x_{2}\left(\mathrm{H}_{2}\right)$ is calculated from eq 1 .

Principal sources of error are (1) in $P_{\text {obs }}$. the uncertainty in extrapolating the two straight lines to

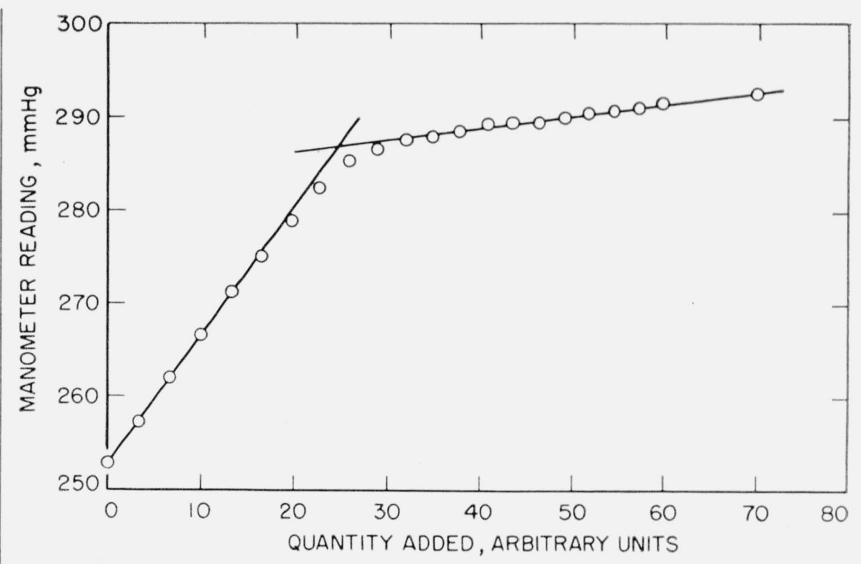

Figure 5. Data of a run for the determination of the dew-point pressure of a mixture.

Run L, $0.752 \mathrm{H}_{2}, 0.248 \mathrm{HD}, \mathrm{T}=18.00^{\circ} \mathrm{K}$.

their intersection and $(2)$ in $P_{\text {calc }}$. the uncertainty in the composition. Estimated errors in $P_{\text {obs }}$ are shown in the table. They are greater for the $\mathrm{H}_{2}-\mathrm{D}_{2}$ mixtures than for the $\mathrm{H}_{2}-\mathrm{HD}$ mixtures because of the greater slope of the two-phase part of the isotherms of the former. Compositions of mixtures determined in the mass spectrometer differed from those determined by mixing pressures by an amount sufficient to cause the errors shown in the tabulated values of $P_{\text {calc. }}$. Mass-spectrometer compositions were thought to be slightly less reliable due to memory effect and to isotopic exchange in the spectrometer. The over-all estimated error is the sum of the errors in $P_{\text {obs }}$. and $P_{\text {calc }}$.

TABLE 10. Dew-point pressures of mixtures of $\mathrm{H}_{2}, \mathrm{HD}$, and $\mathrm{D}_{2}$ in standard $\mathrm{mm} \mathrm{Hg}$

\begin{tabular}{|c|c|c|c|c|c|c|c|}
\hline Run. & $\mathrm{E}$ & $\mathrm{F}$ & G & $\mathrm{H}$ & J & K & $\mathrm{L}$ \\
\hline$T\left({ }^{\circ} \mathrm{K}\right)$ & 20.04 & 19.00 & 20.00 & 18.01 & 18.005 & 17. 03 & 18.00 \\
\hline$y_{1}\left(\mathrm{H}_{2}\right)$ & & 0.499 & 0.440 & 1. 00 & 0.503 & 0.503 & 0.752 \\
\hline$y_{2}(\mathrm{HD})$ & 0.008 & .004 & .004 & 0 & .496 & .496 & .248 \\
\hline$y_{3}\left(\mathrm{D}_{2}\right)$ & .992 & .497 & .556 & 0 & .001 & .001 & 0 \\
\hline$x_{1}\left(\mathrm{H}_{2}\right)$ & & 23 & .20 & & .34 & .33 & 0.61 \\
\hline$P_{01}\left(\mathrm{H}_{2}\right)$ & & 490.8 & 675.7 & 347.2 & 346.5 & 238.1 & 345.9 \\
\hline$P_{02}(\mathrm{HD})$ & 388.2 & 264.7 & 382.8 & . & 176.8 & 114.1 & 176.4 \\
\hline$P_{03}\left(\mathrm{D}_{2}\right)$ & $223 . \overline{5}$ & 145.1 & 219.9 & & 87.5 & 50 & \\
\hline$P_{\mathrm{v}}$, calc & 224.3 & $224 \pm 2$ & $313 \pm 2$ & 347.2 & $234 \pm 2$ & $154 \pm 2$ & $279 \pm 2$ \\
\hline$P_{\mathrm{v}}, \mathrm{obs}_{-}$ & 223.5 & $234 \pm 2$ & $322 \pm 2$ & 348.2 & $240 \pm 1$ & $158 \pm 1$ & $286 \pm 1$ \\
\hline$\Delta P_{-}$ & -0.8 & $10 \pm 4$ & $9 \pm 4$ & 1. 0 & $6 \pm 3$ & $4 \pm 3$ & $7 \pm 3$ \\
\hline $100 \Delta P / P_{-}$ & -.35 & 4.4 & 2.8 & 0.3 & 2.5 & 2.6 & 2.5 \\
\hline
\end{tabular}

Observed pressures are seen to be about 3 percent above those calculated from eq 3 , with an estimated error in the deviations of about \pm 50 percent.

\subsection{Discussion}

The reason for the rounding of the experimental curves in the region of saturation is not clear, but several possibilities may be considered. These will be discussed with reference to the curve for pure $\mathrm{H}_{2}$ (fig. 6) in which the rounding also occurs.

First consider the effect of nonideality of the gaseous hydrogen. This will cause the data to depart from a straight line in the same direction as that observed, but is much too small to account for the actual departure. A plot of the isotherm based on a three-term virial equation with the coefficients 


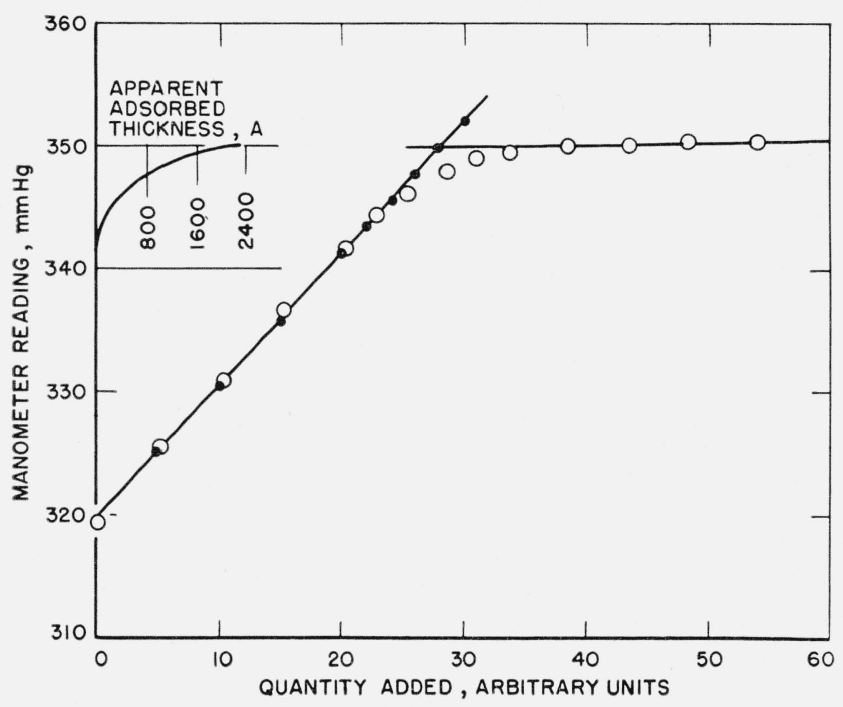

FIGURE 6. Daia of a run using pure $\mathrm{H}_{2}$ in the dew-point pressure apparatus.

Run $\mathrm{H}, \mathrm{T}=18.01^{\circ} \mathrm{K}$, $\boldsymbol{0}$, from virial equation, $\bigcirc$, experimental.

taken from [6, p. 396] is superimposed on the experimental curve. The scale of the abscissa has been adjusted to force the two curves to match in position and slope at one point $(330 \mathrm{~mm} \mathrm{Hg})$. The significant comparison is that while the virial-based isotherm falls within $0.1 \mathrm{~mm} \mathrm{Hg}$ of a straight line, the experimental curve deviates more than $3 \mathrm{~mm} \mathrm{Hg}$ from its extrapolated linear portion. It is of course possible that the three-term virial equation is inadequate to cover peculiar effects, such as molecular aggregation, at pressures very close to saturation.

A more likely cause of the rounding is adsorption of the gas on the walls of the container. (For a discussion of this phenomenon see [16, p. 317 to 329]). Assuming that the horizontal departure of the experimental curve from the straight line corresponds to the quantity of material adsorbed, that the effective adsorbing surface is equal to the macroscopic surface area in the chamber, and that the density of adsorbed material is the same as that of the liquid, the thickness of the adsorbed layer is, as shown in figure 6 , up to about 2000 A near saturation. This appears to be excessive; however, the effective surface area is probably many times the macroscopic area, due to surface roughness, and there is in addition the possibility of capillary adsorption. The surface material was tinned copper sheet and tinned copper tubing. The chamber volume contains many baffles and also a close-wound helix of copper tubing, so the existence of many crevices at contact points of parts of the structure is quite probable. It seems reasonable that these conditions could account for the large apparent adsorption thickness. If we can accept the adsorption explanation, then the intersection of the extrapolated straight lines is the correct dew point for the mixtures.
The making of the measurement,s was greatly assisted by George 'T. Furukawa, Raymond A. Nelson, and Dino Zei.

\section{References}

[1] D. M. Dennison, A note on the specific heat of the hydrogen molecule. Proc. Roy. Soc. (London) 115, 483 (1927).

[2] Harold C. Urey, F. G. Brickwedde, and G. M. Murphy, A hydrogen isotope of mass 2. Phys. Rev. 39, 164 (1932).

[3] David White, Abraham Solomon Friedman, and Herrick L. Johnston, The vapor pressure of normal hydrogen from the boiling point to the critical point. J. Am. Chem. Soc. 72, 3927 (1950).

[4] Robert D. Arnold and Harold J. Hoge, A test of ideal solution laws for $\mathrm{H}_{2}, \mathrm{HD}$, and $\mathrm{D}_{2}$. Vapor pressures and critical constants of the individual components J. Chem. Phys. 18, 1295 (1950).

[5] E. R. Grilly, The vapor pressures of hydrogen, deuterium, and tritium up to three atmospheres. Los Alamos Report LADC-773 (July 11, 1950). Dr. Grilly has informed us by letter that he now has data on more highly purified tritium and obtains vapor pressures somewhat lower than those given in report LADC-773. The tritium curve of figure 1 is shifted slightly to agree with Grilly's later results.

[6] Harold W. Woolley, Russell B. Scott, and F. G. Brickwedde, Compilation of thermal properties of hydrogen in its various isotopic and ortho-para modifications. J. Research NBS 41, 379 (1948) RP1932.

[7] Harold J. Hoge and James W. Lassiter, Critical temperatures, pressures, and volumes of hydrogen, deuterium, and hydrogen deuteride. J. Research NBS 4y, 75 (1951) RP2229.

[8] Harold J. Hoge, Vapor pressure and fixed points of oxygen and heat capacity in the critical region. J. Research NBS 44, 321 (1950) RP2081.

[9] Harold J. Hoge and Ferdinand G. Brickwedde, Establishment of a temperature scale for the calibration of thermometers between $14^{\circ}$ and $83^{\circ} \mathrm{K}$. J. Research NBS 22, 351 (1939) RP1188.

[10] A. Fookson, P. Pomerantz, and E. H. Rich, The prepa ration of high-purity hydrogen deuteride. Science 112, 748 (1950).

[11] The NBS-NACA tables of thermal properties of gases. Table 7.50, Vapor pressure of three hydrogens. Compiled by Harold J. Hoge and Robert L. Powell. Preliminary issue (Sept. 1950)

[12] P. G. Cath and H. Kamerlingh Onnes, Vapor pressures of hydrogen in the neighborhood of the boiling point and between the boiling point and the critical temperature. Commun. Phys. Lab. Univ. Leiden 152a (1917).

[13] David White, Abraham Solomon Friedman, and Herrick L. Johnston, The direct determination of the critical temperature and critical pressure of normal hydrogen. J. Am. Chem. Soc. 72, 3565 (1950).

[14] G. N. Lewis and M. Randall, Thermodynamies and the free energy of chemical substances (McGraw-Hill Book Co., Inc., New York, N. Y., 1923).

[15] R. B. Scott, C. H. Meyers, R. D. Rands, Jr., F. G. Brickwedde, and N. Bekkedahl, Thermodvnamic properties of 1,3-butadiene in the solid, liquid, and vapor states, J. Research NBS 35, 39 (1945) RP1661.

[16] S. Brunauer, The adsorption of gases and vapors, I (Princeton University Press, 1943).

Washington, January 22, 1951. 